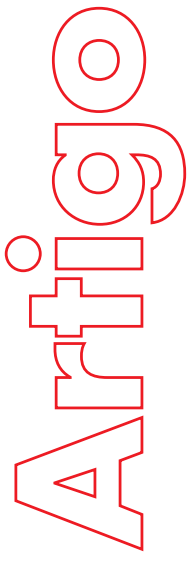

revista

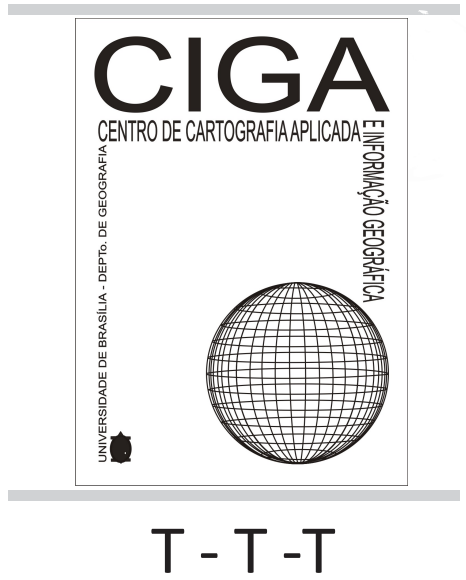

Revista Eletrônica:

Tempo - Técnica - Território, V.2, N.2 (2011), 1:49

ISSN: $2177-4366$

DOI: https:// doi.org/10.26512/ ciga.v2i2.15414

\section{GEOGRAFIA E PLANEJAMENTOO: O USO DO TERRITORIO - GEOPOLITICA.}

\section{MILTON SANTOS}

p. $01-49$

Como citar este artigo:

SANTOS, M. GEOGRAFIA E PLANEJAMENTO: O USO DO TERRITÓRIO GEOPOLÍTICA.

Revista Eletrônica: Tempo - Técnica - Território, v.2, n.2 (2011), p. 1:49 ISSN: 2177-4366.

DOI: https://doi.org/10.26512/ciga.v2i2.15414

Disponível em: http://inseer.ibict.br/ciga/index.php/ciga/article/viewFile/72/57

Este obra está licenciado com uma Licença Crea tive Commons Atribuição-NãoComercial 4.0 Inter nacional. 


\author{
Prof. Dr. Milton Santos
}

\title{
GEOGRAFIA E PLANEJAMENTO: O USO DO TERRITÓRIO - GEOPOLÍTICA.
}

V SEMANA DE GEOGRAFIA - EM 16 DE OUTUBRO DE 1980

RESUMO: O texto apresentado é fruto da conferência “Geografia e planejamento: o uso do território - geopolítica”, proferida no dia 16 de junho de 1980 pelo Prof. Milton Santos, a convite do Departamento de Geografia e do Centro Acadêmico de Geografia da Universidade de Brasília. A transcrição é um documento importante do sentimento do conferencista que regressava ao Brasil após muitos anos de exílio. É um texto crítico e irônico às universidades e aos trabalhos insuficientes de professores e profissionais da geografia. Revela também as lacunas da geografia brasileira e da necessidade de mudanças no exercício profissional por parte dos geógrafos e geógrafas.

Palavras - chave: Geografia brasileira, território, planejadores, natureza, geografia nova, Milton Santos, geografia urbana, geopolítica

\begin{abstract}
The present text is the result of the conference "Geography and planning: the use of the territory - geopolitics”, pronounced on June 16, 1980 by the Professor Milton Santos, at an invitation of the Department of Geography and by the Academic Center of Geography of the University of Brasilia. The transcription is an important document of the feeling of the speaker who returned to Brazil after many years of exile. It's a critical and ironic text to the universities and to the insufficient works from the professors and professionals of geography. It also reveals the gaps of the brazilian geography and the need of changes in the professional practice by the geographers.
\end{abstract}

Keywords: Brazilian geography, territory, planners, nature, new geography, Milton Santos, urban geography, geopolitics. 


\section{APRESENTAÇÃO}

Milton Santos, a convite do Departamento de Geografia e do Centro Acadêmico de Geografia, proferiu conferência em 16 de junho de 1980 com o título “Geografia e planejamento: o uso do território - geopolítica.” A conferência ocupou a manhã e a tarde desse dia e despertou vivo interesse por parte dos professores e estudantes presentes. O que marcou o evento foi a combatividade e senso crítico do grande geógrafo-humanista Milton Santos. Ressalte-se que são passados trinta e um anos do evento, quando Milton Santos regressava ao país após muitos anos de exílio. Todavia, como em suas obras, Milton Santos cobra dos docentes, pesquisadores e estudantes de Geografia trabalho mais sério e crítico. Dá exemplos de suas próprias atividades em diversas partes do mundo e critica o comodismo dos que não buscam dados da realidade para aprofundar suas aulas e/ou pesquisas. Em muitas passagens, com fina ironia, refere o apoio que instituições brasileiras oferecem a pesquisadores estrangeiros, em detrimento dos geógrafos nacionais.

Os debates se iniciaram com convidados especiais, os professores Marcos Formiga, Ricardo Libanez Farret e a geógrafo Dilma Seli Pena, que abordaram temáticas das próprias vivências profissionais com relação à conferência do professor Milton Santos. Igualmente foi dada a palavra a professores e estudantes da plateia. A todos o conferencista respondeu, aproveitando para aprofundar suas críticas às universidades e trabalhos insuficientes de professores e profissionais da geografia. Quando criticado pelo suposto pessimismo de sua fala, Milton Santos emocionou-se e revelou sua insatisfação em ser considerado "professor visitante em seu próprio país”, reverberando as dificuldades em ser contratado por universidades brasileiras, inclusive a UnB. Na ocasião, foi muito aplaudido pelos presentes.

Após tantos anos passados, o resgate das fitas e a degravação da conferência documenta para a historiografia da geografia brasileira momento importante da personalidade e do pensamento de Milton Santos. Revela também as lacunas da geografia brasileira e da necessidade de mudanças no exercício profissional por parte dos geógrafos. Consideramos que, escoimadas algumas questões superadas com o transcurso do tempo, há no conteúdo apresentado abaixo uma lição a ser repassada para a reflexão dos atuais e futuros profissionais da geografia, sobretudo para os professores universitários.

Ignez Costa Barbosa Ferreira \& Aldo Paviani,

Brasilia, 28 de novembro de 2011. 


\section{PRESENTATION}

Milton Santos, at the invitation of the Department of Geography and by the Academic Center of Geography, gave a lecture in June 16, 1980 titled “Geography and planning: the use of the territory - geopolitics.” The conference held the morning and the afternoon of that day and aroused great interest among the present teachers and students. What marked the event was the combativeness and critical sense of the great geographer-humanist Milton Santos. It should be noted that are passed thirty-one years of the event, when Milton Santos returned to the country after many years of exile. However, as in his works, Milton Santos charges from the teachers, researches and students of geography a work more serious and critical. He gives examples of his own activities in a lot of parts in the world and he criticizes the convenience of those who doesn't seek for data about the reality to deepen they classes and researches. In many parts, with refined irony, he refers about the support that the Brazilian institutions gave to the foreign researchers, to the detriment of national geographers.

The discussions began with special guests, the professors Marcos Formiga, Ricardo Libanez Farret and the geographer Dilma Seli Pena, who addressed some thematic of their own professional experiences regarding the conference of the Professor Milton Santos. It has also been given the word to the teachers and students from the audience. He replied to all to all the speakers, taking the opportunity to deepen their critics to the universities and insufficient works of teachers and professionals of geography. When criticized for the supposititious pessimism of his speech, Milton Santos moved up and revealed his dissatisfaction at being considered "visiting professor in his own country", echoing the difficulties in being engaged by Brazilian universities, including UnB. At the time, he was much applauded by those present.

After so many years past, the redemption of the tapes and the record of the conference documents to the historiography of the Brazilian geography represent an important moment of the personality and the thought of Milton Santos. It also reveals the gaps of the Brazilian geography and the need for changes in the professional practice by the geographers. We believe that, now that some issues have been solved with time, the content present below is a lesson to be passed for the reflection of the current and future professionals of geography, especially for the academic teachers.

Ignez Costa Barbosa Ferreira \& Aldo Paviani,

Brasília, 28 de novembro de 2011. 


\section{Abertura da Conferencia do Professor Doutor Milton Santos foi relizada pelo Professor Aldo Paviani}

Na seção da manhã de hoje convido para comporem a mesa o professor Milton Santos, a professora Margarida Penteado, diretora do Instituto de Ciências Humanas, os nossos debatedores prof. Manuel Formiga, professor Ricardo Farret e a colega Dilma Seli Pena.

Brevemente, uma vez que são dispensáveis maiores apresentações de nosso conferencista, de todos conhecido. Tenho a grata satisfação de tê-lo entre nós, professor Milton Santos, sabendo tão ocupado. Nós antecipadamente agradecemos a aquiescência em falar nesse auditório (da Reitoria) e esperamos que, dentro do estabelecido, de manhã, ouviremos o conferencista e, à tarde, os debatedores farão suas intervenções. Depois da conferência do professor Milton Santos, abriremos ao público para que se inscreva através de perguntas por escrito aos demais organizadores da V Semana Geografia da UnB.

Desde logo passo a palavra ao professor Milton Santos.

Prof. Milton Santos:

\section{GEOGRAFIA E PLANEJAMENTO: O USO DO TERRITÓRIO - GEOPOLÍTICA}

Devo dizer que me considero extremamente honrado de vir a ocupar, ainda que por algumas horas essa alta cátedra. E devo confessar a grande emoção por aqui encontrar velhos e novos amigos. Mas também devo agradecer a delicadeza da apresentação feita pelo meu amigo Aldo Paviani.

Dito isso, caber-me-ia acrescentar que é com grande honra, mas também com grande medo que me ponho dentro deste auditório. Os auditórios são, como sabemos, uma incitação à vaidade, ao gosto da representação, e ao risco das concessões, isto é do facilismo. Ora, todavia estamos numa universidade, que é sempre uma grande tribuna, ainda quando ela esteja ou pareça arruinada.

Todavia, o intelectual é sempre capaz de ser surpreendente, isto é de dizer e fazer o que dele não se espera no momento " $x$ ”, de mudar de opinião, de vencer as inércias ou as pressões e de exprimir-se na única língua própria de um intelectual, que é a língua da verdade. 
O intelectual não é o professor. O professor não é o intelectual. O intelectual pode ser professor. O professor pode ser intelectual, mas a duas coisas não são forçosamente as mesmas. O intelectual é o homem que tem o gosto ao risco, sem o qual não há descoberta. O intelectual é aquele que se dispõe a se indispor com os que o ouvem para trazer a verdade em que acredita naquele momento, que tem a coragem de ir descobrindo que essa verdade não é mais, voltar atrás, isto é, dar um passo a frente trazendo a nova verdade. A necessidade do risco é fundamental e se as nossas universidades estão como estão apodrecidas é exatamente porque essa disposição para o risco não é mais a companheira do professor. O professor, figura que já quase não existe na universidade, da mesma maneira que na universidade já quase não existem estudantes. Ora o risco é indispensável na universidade que é matriz do futuro e é bem dispensável porque o futuro não é um, o futuro são muitos.

O tema que vou aqui falar, dentro do espírito dessa introdução é aquilo que me foi sugerido, isto é, geografia e planejamento. Ousei colocar como subtítulo o que chamaria de uso do território, ou seja, a geopolítica.

Em primeiro lugar, tanto geografia como planejamento conhecem uma definição e uma prática que estão muito aquém de seu significado e de suas reais possibilidades tanto a geografia como o planejamento apenas levantam uma ponta do véu da realidade que são ambos postos a ensinar estudar e praticar. Me refiro o planejamento que se ensina nas universidades é aquele que se pratica nos órgãos de planejamento. Me refiro à da geografia que se ensina, que se aprende para ensinar e que se pratica. A relação entre a geografia que praticamos e o planejamento que praticamos é uma relação vazia entre duas ambiguidades. Propusera-me, então, senhores um tema irreal. Irreal porque tem perdurado como um dado fatal e letal causa da degradação da formação em ambas as carreiras, quem sabe é o momento de abrir um debate nacional para chegar e as universidades têm o dever de enfrentar esse debate prisioneiras desse amor à verdade de que falamos que, supunha, do risco.

Ambos, geógrafos e planejadores saem atônitos de suas respectivas escolas ou institutos, tanto mais atônitos quanto mais avançados em estudos. As especializações e pós-graduações nesse país em geografia parecem deformar ainda mais do que formar o estudante já mal formado na graduação. Obrigados por isso os que saem desses cursos a mergulhar na impotência que pode desembocar no charlatanismo ou no desespero, mas que em todo caso não o habilitam a um real serviço ao país, deformados enquanto profissionais e enquanto cidadãos tornam-se, com diploma na mão, deformadores.

A geografia, sobretudo depois que o seu ensino foi atrelado ao do planejamento cometeu um grande equivoco, não digo isso em regra geral, mas o grande equívoco de imaginar de o que se deseja, quando o que se deseja é apenas um aspecto do que se pode fazer, viu reduzido o seu campo de ação, porque reduzida sua área de visão. Ora, a realidade que nos cerca é que é o material com que dizemos trabalhar, na medida em que a geografia supostamente, por causa do mercado de trabalho, que rapidamente se 
mostrou exíguo, decide orientar a sua formação em função do planejamento. Nesse caso, a geografia reduz as possibilidades de formação do geógrafo. Reduz as possibilidades de progresso do professor. Reduz as possibilidades de formação de pesquisadores e contribui para formar mal aquilo que se chama planejador e mal aquilo que se chama geógrafo.

Do real de que partimos ao ideológico em que chegamos forma-se um caminho sem volta porque a universidade deve ser como cada homem, isto é, ter permanentemente a preocupação com o futuro, quem de nós se preocupa apenas com o presente não chega a se um homem, a universidade que se preocupa apenas com o presente não é universidade. O homem tem sempre um projeto e a universidade tem como um dos seus deveres ajudar a formular o projeto da nova nação. A nova nação é a nação que está sempre surgindo daquela que é, sobretudo, uma nova nação é aquela que surge de um processo de reconstrução nacional, como a que vamos enfrentar daqui a pouco porque não escapamos das realidades internacionais nem podemos escapar do movimento próprio da sociedade brasileira. Ora, o que me parece é que estamos, no Brasil, muito próximos de enfrentar a concretização de um novo pacto social. E aqui vale apena fazer pequeno parêntese para distinguir o que é um pacto de o que é um pacote. As palavras parecem semelhantes, mas não são; não podem ser. O pacote é um planejamento unilateral destinado a paralisar, ou ao menos entorpecer a marcha da historia. Isso gera cristalizações e violências. Um pacto é o reconhecimento pelas partes de uma evolução necessária de uma evolução necessária cuja santificação por um acordo que se impõe e se faz. Mas um acordo aberto, aberto a nova evolução a novos progressos, um acordo que é destinado a se desfazer durante o curso da historia para dar lugar a outro acordo, seja pela violência, ou seja, pelo consenso, e a história, já dizia o geógrafo e filosofo Merleau-Ponty, é um progresso sem fim.

Não basta assim, não basta, todavia, distinguir pacto e pacote da maneira que fiz. Há de ir mais longe porque o pacto abrange a totalidade dos aspectos e é apresentado como esse conjunto desses aspectos, enquanto o pacote abrange um ou dois aspectos e os trata de forma isolada, alterando a totalidade dos aspectos através de uma ação seletiva. Ora, e aí entramos no assunto, nos dias de hoje não há pacto social que não seja também um pacto territorial. Nos dias de hoje e também nos dias de ontem, mas muito mais nos dias de hoje do que nos dias de ontem. O que é que faz uma sociedade, num país dado, para sobreviver e para enfrentar o futuro que se faz através de certo uso do território. O que se faz através de certo uso do território pelo que chamamos a sociedade, a economia e a política. Isso sempre se fez. Quem entre nós lê, por exemplo, Vauban economista clássico e, sabemos todos que os economistas clássicos eram igualmente grandes geógrafos. O ultimo dos economistas clássicos e o primeiro dos economistas revolucionários, Marx, se não tratou o espaço da forma como ele foi tratado, por exemplo, por Adam Smith, ou o citado por mim, Vauban, todavia dedicou uma grande parcela do seu trabalho ao espaço, apesar de geógrafos marxistas imaginarem que Marx 
jamais tratou do espaço. Todavia, eles não souberam fazer a leitura adequada do espaço. Recomendo em particular a leitura do capitulo 13 do Capital, que, de fato, fala da cooperação. Recomendo igualmente a leitura do capítulo sexto, inédito, do Capital, aquele que liga o volume primeiro com o volume segundo, onde nós vamos encontrar uma quantidade enorme de elementos, que nos permitem tratar, trabalhar, o espaço, evidentemente seguindo se quisermos a regra do método marxista, isto é, o trabalho em função da história real das coisas e dos homens.

Ora, o que se passa no mundo de hoje? O mundo de hoje na era técnico e cientifica em que vivemos, o que mais apreciamos é o aumento do tamanho dos objetos geográficos, jamais os objetos geográficos, e objeto geográfico é tudo que existe na natureza já modificada pelo homem ou ainda aparentemente intocada por ele, a natureza como todos sabem é o conjunto de todas as coisas. Ora, esse conjunto de todas as coisas que a natureza nos dias de hoje exibe objetos de um tamanho como jamais antes houve, é o grande salto da era que se instalou nos anos 1945. Mas, os objetos fixos, fixados ao solo, são, como jamais antes houve, portadores de uma intencionalidade, exatamente porque estamos na era técnico-científica e os objetos são como jamais foram portadores de um conteúdo técnico que lhes atribui uma função precisa dentro da sociedade. Todavia, uma vez construídos eles se tornam natureza, espaço geográfico, intervindo assim na elaboração da sociedade, da economia, da política, mas também da cultura e da moral. Esse conteúdo técnico dos objetos, essa intencionalidade dos objetos é que fez com que a nossa disciplina tão maltratada, tão pouco importante, a menos importante das disciplinas sociais. Nós somos entre os que participam e formam a universidade aqueles que dispõem de menor prestigio. Os reitores, de um modo geral, se contentam em imaginar que nos contentam dando-nos aqueles pequenos recursos para excursões. Lembrando-se dos tempos em que faziam a geografia e sem curiosidade para compreender a geografia nova que se impõe ao mundo e a esse país, em particular, pelas suas dimensões. Ora, a geografia tornou-se não a que ensinamos, mas a que vamos ter que ensinar daqui a pouco, porque as necessidades do país o exigem; não a que sabemos, mas a que vamos ter que fazer daqui a pouco. Porque as necessidades do país a exigem. Essa geografia que aí está não perdurará, entre os departamentos de geografia que aí estão, não perdurarão. Porque não podem permanecer em contraposição à realização da história do mundo e do país. Então, temos esperanças. Não, a esperança de termos o prestígio pessoal para arrecadar verbas dos ministérios, do CNPq ou da FINEP, mas a possibilidade de prestarmos um real serviço a nossa nação, que é o nosso dever. Então, como dizia, e todo mundo sabe, uma sociedade, uma economia, um estado se realizam através de funções, a função é a ação, é a ação da estrutura social cristalizada no poder, todos os tipos de poder, é a ação da economia é a ação do político, são as funções, e o espaço como era antes, mas como, sobretudo, é hoje, é o lugar final da ação. O espaço é o lugar final da ação não apenas como lugar filosófico da ação, mas como lugar geográfico da ação, e o espaço é também o instrumento da ação. Daí, o fato de que todo avanço social, econômico e político se faz através de um pacto territorial. Eu vou dar alguns exemplos, por acaso brasileiros. Vejamos, por exemplo, a 
constituição de 1946. Imagino que a maioria das pessoas que estão aqui, algumas não deve ter noção do que é uma constituição e certamente um grande numero não é do tempo da constituição de 1946, eu também não, mas ouvi falar dela e a estudei. Na constituição de 1946 nós vimos, animado pelo então deputado Aliomar Baleeiro e sugerido por um grupo de meninos, que em diversos lugares do Brasil, tentavam um acordo chamado municipalismo, isto é, planejamento sem consultorias, sugerir coisas. Nessa constituição aparece a divisão igualitária entre todos os municípios de uma parcela do imposto da renda, isso desencadeou um movimento de redivisão territorial do país, a criação de uma quantidade de municípios, isto é, uma reorganização da geografia e da sociedade brasileira através de uma decisão política, isto é, um pacto territorial, um pacto geográfico. Pacto que a geografia não estuda, de que a geografia não se ocupa, de que a geografia não quer saber, que não interessa ao geógrafo, que não faz parte do nosso trabalho.

Temos também a revolução de 1932, dita constitucionalista. Revolução que teria sido feita para impor ao senhor Getúlio Vargas, chamado de ditador por aqueles que fizeram a revolução de 32, a revolução paulista, que aparece como sendo um movimento para restaura a democracia, que na realidade correspondia às novas realidades emergentes do país, isto é a industrialização do Brasil no espaço paulista, porque jamais houve e até hoje não existe indústria paulista, o que existe é uma indústria brasileira localizada em São Paulo por razões políticas, sociais e econômicas, sobretudo razões geopolíticas. Geográficas, malgrado geógrafo, essa revolução de 1932 tinha como objetivo entre outros, qual? O de abolir as fronteiras nesse país, dos estados federados, o de eliminar as dificuldades apostas à passagem de mercadorias para que São Paulo pudesse, a partir daí, vender em todo país e aumentar, por conseguinte, as possibilidades de expansão do seu parque industrial. Depois de 1932*, dos que fizeram a revolução... Dos que fizeram a revolução alguns se mostraram contentes com o próprio chamado ditador, uma vez que o objetivo real, que não era obrigatoriamente conhecido por aqueles que lutaram, mas era conhecido dos que os levaram a lutar, tinha sido atingido: Um novo pacto territorial. Com uma mudança da distribuição dos homens, das atividades, da riqueza no país. E, durante o governo do Senhor Kubitschek, o que é senão um pacto territorial, o fato de havermos construído essa cidade em que estamos, Brasília. Brasília faz parte de um pacote territorial, um pacote territorial que inclui a SUDENE, que inclui aqueles bilhões de Cruzeiros dados ao Senhor Carlos Lacerda para que pudesse embelezar e reabilitar a cidade do Rio de Janeiro e, que, sobretudo, permitia a São Paulo, outra vez, aumentar o seu potencial de comando sobre o país, uma vez que, Brasília criada haveria que expandir a rede de estradas. Ora, todos sabemos que sem circulação não há industrialização que possa prosseguir de maneira feliz. E o pacote eleitoral de 1977, não é ele também um pacto territorial? Na medida em que o país foi redividido em circunscrições eleitorais cujo valor, cujo peso, na construção do Congresso, foi também modificado. É também um pacto territorial. O uso do território de certa maneira, é uma formalização do território de certa forma de maneira a permitir que a situação vigente 
pudesse permanecer no comando da coisa política, ou facilitar-lhe a permanência nesse comando, assegurando-lhe a formalidade, à qual somos brasileiros tão sensíveis, porque mais positivistas nós somos do que os franceses, que inventaram o positivismo. O certo é que isso é igualmente um pacto territorial, como um pacto territorial é a criação do Imposto da Circulação de Mercadorias (ICM). Vejam bem, esse ICM, que certamente os senhores estudaram nas suas aulas, imagino, que, se não estudaram, devem exigir rapidamente dos professores que dêem aulas sobre isso. Talvez não possam dar, porque as universidades não têm acesso aos dados. A universidade é um lugar onde há briga de conceitos e briga de livros, os dados têm que ser comprados. Antigamente, o IBGE vendia os dados para as universidades, atrofiando a pesquisa e impedindo que os professores, e os estudantes tivessem a possibilidade de prestar melhor serviço ao país, obrigando-os a trabalhar no vazio que a universidade é... (para estarmos um pouco mais próximos da realidade temos que sair dela, universidade). Na medida em que os dados que às vezes são fornecidos gentilmente aos nossos colegas estrangeiros, me refiro, por acaso, aos estudos da urbanização desse país, onde os dados chamados sigilosos foram entregues tranquilamente aos geógrafos estrangeiros que por sinal conduziram um trabalho de péssima, não é verdade? Enquanto a nós outros, cidadãos do país a que queremos servi-lo, esses dados não são de maneira nenhuma abertos. Deve ser realmente registrado.

Esse ICM, a quem beneficia? Ele beneficia, sobretudo, aqueles municípios onde há uma massa de trabalhadores suscetíveis de mostrarem sua irritação. Para onde vai a maior parte do ICM nesse país, vai para as periferias urbanas onde, como diria Hegel, para não citar Marx pela segunda vez, a quantidade se transforma em qualidade e os trabalhadores podiam um dia se manifestar de uma forma desagradável os seus desencantos. Então, se a gente pega essas estatísticas e essas estão disponíveis. Aliás, outro parêntese: a formação teórica que falta aos geógrafos permite usar dados secundários de maneira a chegar a algumas conclusões. Desde que o jovem tenha uma formação teórica, que sempre falta. Ora, o que acontece é que esses municípios, São Bernardo, Santo André, São Caetano, a gente pega aquelas estatísticas muito simples, publicadas de imprensa, publicadas na Emplasa e vê que esses municípios todos têm mais serviços e melhores que o município de São Paulo. Quer dizer que a criação do ICM não foi inocente, ela constitui uma forma de uso do território nacional e dos recursos da nação de modo a amortecer as pretensões, as reivindicatórias dos operários, ali onde eles têm um maior poder de reivindicação. Agora vou citar Sartre, por efeito da vizinhança. E todo mundo sabe que ele é o efeito fundamental da transformação da chamada quantidade na qualidade. Me desculpem citar de vez enquanto, mas todo mundo sabe que na universidade é de bom tom uma pitada de pedantismo. Ora, a federação constitui também um pacto territorial e é por isso que a federação jamais foi, no decorrer da história que a criou, 'mais ou menos artificialmente' a mesma... A federação brasileira, através da história do Brasil, ainda que sem mudanças brutais na nossa história política, e também, um momento de mudança brutal nessa história 
política, mostra, apesar do rótulo, uma realidade que não é a mesma, isto é, mais uma vez um impacto territorial.

E as regiões metropolitanas? Porque foram criadas? Se não por uma vez mais... a realização prática de um pacto territorial, que é uma região metropolitana. O que é uma região metropolitana? Definição formal: Região metropolitana é formada por um município enorme, cercado de municípios grandes se são pobres ou pouco povoados e municípios pequenos se neles há uma população operária. Isso é uma região metropolitana, a definição formal. Definição, digamos assim, de conteúdo: uma região metropolitana é uma área que desborda as fronteiras do município porque é preciso manter a unidade de certas infraestruturas. As infraestruturas que são fundamentais para o exercício da economia, para o exercício do capital tem que ter um comando único, daí a criação de uma região metropolitana, tanto quanto seja necessário esse comando único, para que a economia moderna possa transitar mais livremente no território, assim chamado região metropolitana. Tanto isso é verdade que os organismos incumbidos do planejamento, que se imaginam incumbidos do planejamento da região metropolitana, não fazem nada, ou quase nada pelas populações, exceto os transportes. Mas, destaco os transportes por duas razões: porque os transportes são, sobretudo, vitais à realização da economia no momento atual e também porque é a forma pela qual se reduz o cansaço do trabalhador reduzindo-lhe, de um lado, o desgaste que levaria a uma produtividade menor e reduzindo-lhe a agressividade, todavia manifestada de tempos em tempos, no que se denominou chamar quebra-quebra. Ora, esses pactos territoriais são objetos do nosso trabalho. Não são geógrafos? Mas nós trabalhamos com livros e não com a realidade. A realidade não nos interessa. Que coisa é essa da realidade? Na universidade, a realidade? Não, são livros que nos interessam? Nem mesmo os livros. Nós trabalhamos com Xérox, isto é, pedaço de livro. O grande lugar de atração da universidade não é na biblioteca, como deveria ser, mas aquela portinha onde xerocam as coisas. Mas se xeroca sobre tudo os autores estrangeiros. Desembarcando nesse país após uma longa ausência, foi com enorme tristeza que vi nas livrarias a abundância de livros estrangeiros, em geografia. Uma editora parece que era subvencionada diretamente por um governo estrangeiro, ou algo parecido, para nos impor essa literatura. Essa editora que agora, por razões da crise internacional, está sendo obrigada a publicar livros de autores brasileiros, e como ela quer publicar de uma vez doze, é possível que publique livros ruins, porque um livro não se fabrica como se fabrica um sorvete.

Enfim, haveria de acrescentar que há dois tipos de pactos territoriais. Há o pacto territorial que é apenas funcional, e há o pacto territorial que se pretende estrutural. $\mathrm{O}$ pacto territorial funcional contempla um aspecto da realidade toda. $\mathrm{O}$ pacto territorial estrutural contemplará, porque ainda não houve este, todos os aspectos da realidade. Os pactos territoriais que temos assistido nesse país e em muitos outros, são pactos territoriais funcionais. O pacto territorial estrutural ainda que não seja praticado, tem 
que ser aprendido, tem que ser estudado, e aí temos que fazer um recurso à história para poder continuar nosso raciocínio. (vou beber um pouco de água, fazer uma pausa, tenho direito a um pouco de água) Hoje ninguém mais procura esconder o fato de que há uma crise internacional, essa crise internacional que vai desemborcar numa nova ordem internacional. É verdade que se fazem reuniões, ali, aqui e acolá, na busca dessa nova ordem internacional, que, todavia, já foi delineada, há coisa de quinze anos, pelo homem mais inteligente do Hemisfério chamado Ocidental, eu digo chamado Ocidental porque nós é que somos o Ocidente. A Europa é o Oriente, exceto Bordeaux e a Inglaterra, que estão a oeste de Greenwich. A Europa é Oriente e aqui, mas se diz que o Ocidente é aquilo lá por razões de ordem cultural, histórica, política. Quanto a essa Nova Ordem Internacional, já está em prática há quinze anos, comandada por organismos como Banco Mundial, como o Fundo Monetário Internacional, ajudados pelas fundações corporativas, como a Fundação Ford, ou a Fundação Rockfeller e que estão impondo ao mundo uma nova ordem enquanto nós outros comparecemos nas ribaltas, discutindo a nova ordem que queremos. A luta já está se realizando.

Não vou entrar em detalhes agora, para não alongar o discurso, mas me ponho à disposição para responder as perguntas e lamento que não haja algumas perguntas hoje mesmo depois da conferência. Eu tenho medo de que aquela coisa de esquentar a sala fique um pouco prejudicada se apenas começamos pela tarde, mas eu sou, como todo mundo sabe, extremamente disciplinado, não é que eu ignore isso. De modo que, se a mesa, presidida por um homem, que é, sabidamente, uma pessoa sensata, decidir em contrário eu não farei nenhuma má-criação pelo menos em público.

Então, a nova crise internacional é correspondida por uma nova ordem interna em cada país. Cada vez que se cria uma nova ordem internacional, se cria uma nova ordem interna. Ora, nenhum país deixará de ser atingido por essa nova ordem internacional, que está se reformulando. Alguns países serão mais atingidos que outros, e entre esses países está aquele em que vivemos que é o Brasil, porque, pelo fato de que o Brasil é um país que dispõe, ao menos em parte dele, infraestruturas, que dispõe de um potencial energético muito grande, que dispõe de cidades abertas como são ao capital estrangeiro e que oferecem esse capital estrangeiro, pelo fato de serem cidades, simplesmente. $\mathrm{O}$ clima ideal para que ele floresça e dispõe de mão de obra barata indefesa como é a nossa. Ora, essa nova ordem internacional vai obrigar em toda parte a uma remodelação do território: formas diferentes de uso de território, uso de território pelo poder político, uso de território pelo poder econômico, uso de território pela população e, quem sabe, de destruição moral ou reconstrução moral, porque a cultura e a moral estão intimamente ligadas à forma como o território é usado. Não esquecer isso. É exatamente a nova ordem mundial vai mudar a geografia do mundo e de cada país em particular, pelo fato de que jamais, como hoje, se usam matérias primas vindas de toda parte e jamais, como hoje, a base material da produção é tão estreita, tão limitada, tão escassa, tão geograficamente localizada. 
Jamais houve um tão grande movimento de pessoas na primeira fase do imperialismo. O que havia era migração dos europeus para os países chamados novos ou recentemente colonizados, nesta fase da história, aquele proletariado exterior de que falava Toimbee, se desloca para os países portadores das possibilidades de produção. Jamais como hoje a economia se internacionalizou, chegando, quem sabe, a derradeira etapa de sua internacionalização, isto é, a internacionalização do produto. Quem sabe, dentre nós, de onde veio a matéria com a qual rodamos os nossos carros, os carros de vocês, porque eu não tenho carro, com a qual nos rodeamos em nossa casa e até a roupa que, às vezes, cobre os nossos corpos, quem sabe de onde veio essa matéria-prima ou a já transformada? Não sabemos. Já nem nos perguntamos, porque não perguntamos nada. Mas a verdade é que o produto se havendo internacionalizado, o movimento das coisas se tornou, no mundo, frenético, e a necessidade de circulação à escala mundial são também necessidades de estipulação à escala local. Um país como o Brasil que é um país continental, encontramos nas estradas caminhões que cortam por milhares de quilômetros, produtos, produzidos em pontos muito seletivos do espaço nacional. Esse frenesi da circulação, já nos parece um dado normal. Tudo isso são coisas que nos permitem pensar que o espaço de cada nação e de todas as nações será profundamente remodelado como resultado na crise na qual estamos, da qual não vamos sair tão rapidamente, isto é, um novo uso do território, uma nova geografia para a qual, todavia, não estamos preparados. Essa geografia real não é a geografia que se estuda, que se ensina, que se escreve. O nosso trabalho é um trabalho fantasma, porque nada tem a ver com a realidade das coisas que existem.

Mas há também outros dados que nos levam a pensar nessa remodelação territorial. O fato, em particular do Brasil, das possibilidades energéticas, da rede de transportes e o fato de que dispomos de grandes cidades, e todo mundo sabe que nos dias de hoje que a cidade é uma força produtiva. Isso tudo está em Marx, me perdoem os marxista ortodoxos que diga coisas que não estão escritas em Marx. Mas, parece que se ele pudesse me ouvir ele me agradeceria esse acréscimo. (Que bom que tenhamos bons marxistas nessa sala). A cidade como meio de produção, enquanto que o homem urbano se transforma num instrumento da produção. O homem não é mais uma força produtiva apenas, ele é um instrumento da produção num mundo cibernético que faz de cada um de nós um objeto, cuja liberdade de circular, de produzir, de ser, de existir, é limitada. Mas, há também outro fato importante, que deveria ser incorporado aos estudos sobre a reorganização do território, que é a questão da distribuição, da circulação. Nós sabemos que o país organiza o seu território de uma forma, digamos, neutra, e criam estradas de rodagem, de ferro, aeroportos, portos, o diabo, mas a gente se esquece de que essas criações todas não são usadas da mesma forma, nem pelas instituições, nem pelas firmas, nem pelas pessoas. As estradas estão aí, a de ferro e de rodagem, os silos estão aí, os portos aí estão. Mas quem os usa? As firmas não usam igualmente o espaço; as instituições não usam igualmente o espaço; as pessoas não usam igualmente o espaço. Há pessoas que são quase imóveis no espaço, enquanto há pessoas que são 
extremamente móveis no espaço. E o uso do espaço pelas firmas é um dado do seu poder, e o poder de circular no espaço que aparentemente foi construído para todos, é que permite a firma de aumentar o seu lucro, de aumentar uma vez mais o seu poder, de controlar à sua maneira o território, competindo inclusive com as instituições. E esse é um dado fundamental da situação brasileira atual, o uso diferencial do espaço pelas firmas que vai nos ajudar a compreender a geografia desse país hoje e, sobretudo, a geografia desse país amanhã, porque o hoje não nos interessa, simplesmente porque o hoje não existe. O hoje existe no relógio, o presente só é enquanto não se faz, não há presente completo, o presente é apenas a aurora quando ela se mostra, quando ela se faz ela já é passado.

A geografia como qualquer disciplina humana que não se preocupa com o presente não chega a ser uma ciência, é um desafio à razão, e é um instrumento de embrutecimento dos professores e dos alunos e uma forma de desservir a nação. Ora, esse papel do espaço no mundo de hoje, o lugar que o espaço tem como dado filosófico, porque ligado à natureza do homem e esse papel como dado político que o espaço tem, que explica, por exemplo, o grande número de países que existe hoje. Nunca houve tantos países no mundo... Eu era rapaz, isto é, cinco ou seis anos atrás (não faz tanto tempo), quando se dizia tal país é inviável porque tem pouca gente, porque tem pouco espaço. Um dado multinacional: a interação da economia fez com que, nos últimos dez anos, se criassem duas vezes mais países do que existiam antes. O Estado como indispensável à realização da economia transnacional, Estado como dado fundamental das possibilidades de realização das firmas que nós equivocadamente chamamos de multinacionais. Mas há também outras coisas, como, por exemplo, os equipamentos que são dados de presente aos países pobres e recebem como regalo uma quantidade de portos, estradas de ferro e rodagem, linhas telefônicas, etc. para preparar o uso do seu território pelo grande capital estrangeiro. Tudo isso é resultado de ações raciocinadas, que abarcam comportamentos encadeados e em todos os níveis, até o nível do comportamento dos homens. Isso significa que o que o planejamento faz, como eu disse no começo, é um trabalho mínimo, limitado, que abrange aspectos extremamente reduzidos da realidade total, deixada para sua análise, seu estudo, e às vezes, a sua realização, a geopolítica.

Eu disse no congresso de julho, da Associação de Geógrafos Brasileiros, e repito agora, não é por outra razão que o principal ministro do governo brasileiro é um geógrafo (referia-se ao General Golbery do Couto e Silva), é exatamente pelo fato de que o espaço é essa entidade formidanda, essa entidade cujo manuseio, cuja organização é fundamental para atingir desígnios que se estabelecem em função dele, o espaço. Mas a geografia tão pouco se ocupa da geopolítica, quando geografia é geopolítica. Não se trata de discorrer sobre geografia e geopolítica. Geografia é geopolítica.

O que estudamos diante de um território, diante de um país? Deste país, por exemplo. São as transformações todas, seja qual for o período da sua história, transformações que se realizaram mediante ações econômicas, políticas, culturais que vão desembocar no território e nós estudamos o que? O território. Como se ele fosse um dado autônomo, 
razão do nosso total desprestígio (espero que aqui haja pessoas que não sejam geógrafas e que vão espalhar para outros grupos, porque senão o desprestígio vai aumentar mais ainda porque confessado o nosso desprestígio vendo o fato de que nós não compreendemos qual é o nosso trabalho). O que é que a geografia faz? É estudar todas essas ações, quando eu chego a qualquer país, o que eu estou estudando geografia? São todas as ações que se fizeram, no passado remoto ou recente, de todo tipo. O que eu tenho que me preparar para fazer, é compreender de um lado as transformações que estão se dando, o impacto dessas transformações no espaço que nos compete estudar, mas também como as transformações feitas no espaço vão contribuir para que uma dada política possa ser possível, para que uma dada economia possa ser possível, para que uma dada sociedade possa ser possível, para que uma dada cultura seja possível, para que uma dada moral seja possível.

A geografia descritiva analisa o uso do território para fins econômicos, sociais, etc. etc. Mas, quando a gente faz um recurso ao passado e vê o que aconteceu, por exemplo, na China, a partilha da China pelos países então hegemônicos. O que é isso se não um dado geopolítico, que a gente estuda a penas como se fosse uma divisão territorial, um dado formal, da própria colonização. Devemos lembrar que houve colonizadores de diferentes níveis, de diferentes classes. Quem podia mais tomou o que lhe parecia melhor. A Inglaterra tomou o que lhe parecia melhor naquele momento, ainda deixando a França em segundo lugar para coisas que então não eram tão importantes naquele momento histórico como, por exemplo, o petróleo do Saara, o petróleo e urânio do Gabão, ou o urânio do Tchad, não eram tão importantes. A Inglaterra deixou a potência de segunda classe, as colônias de segunda classe. Mas a Inglaterra fez mais, orientada por um geógrafo chamado Mckinder, ela elaborou o plano da África do Leste, que era o seguinte, a África do Leste e britânica é formada pela Tanzânia, Uganda e Quênia. Todo colonizador sabe que um dia ou outro os países deixarão de ser colonizados. Isso está em Hegel. (Fim da fita UM)

(Início da fita DOIS) (...) Os colonizados apelaram ao império para criar no centro desse território formado por três subdivisões, uma área onde se localizariam os brancos, mas onde também se localizaria os instrumentos de modernização, isto é, as ferrovias, as rodovias, os missionários, os professores e inclusive para assegurar a possibilidade de homogeneização do território indispensável ao seu uso mais útil pelo capital. Deveriam criar o que não existia: um rei para etnias que não dispunham de um só rei, criaram uma cidade onde puseram esse rei, que asseguraria em nome do Império Britânico o exercício do poder político, enquanto os hindus trazidos pelos próprios britânicos, antes já trazidos pelos alemães, iriam fazer o trabalho sujo da exploração econômica através do comércio. Esse plano não funcionou, mas foi, sem nenhuma dúvida, um plano inteligente. Todavia outros planos funcionaram como o da África do Sul. O que são os batustans se não uma inteligente utilização do conhecimento geográfico através da geopolítica. Os batustans são, como todo mundo sabe, aquelas áreas reservadas aos 
negros das quais não podem sair se não for para trabalhar e que asseguram a possibilidade de ter, amanhã, a independência desses países incrustados dentro de um território altamente desenvolvido, em certas partes, enquanto essas ilhas de negros altamente subdesenvolvidas, retardando a possibilidade de uma recuperação do país pelos seus donos, os negros. Curioso, e pouca gente sabe disso, é que, na América Latina, houve também uma África do Sul - a Costa Rica. Costa Rica que reservou também um espaço aos negros, indispensáveis à realização dos desígnios da United Fruit. Os negros eram impedidos até poucos anos, dentro desse país que se chama democrático, que se quer um exemplo de democracia na América, de se locomover livremente no território - a África do Sul da América Latina. E nós os geógrafos o que fazemos diante de tudo isso? Alguns de nós, isto é, alguns deles como o senhor McKinder ou como alguns daqueles a quem amamos, mas que serviram servilmente a colonização como Vidal de La Blache, tiveram um papel nesse tipo de negócio. Nós fazemos interpretações a posteriori, aliás, nem fazemos interpretações a posteriori, raramente tomamos em conta a totalidade dos dados, dos fatores.

Eu estou então propondo outra definição para geografia. Em julho propus um hank, que foi a seguinte a geografia, uma filosofia das técnicas, isto é, o que é o homem como dado da natureza diante dela, natureza. É aquele que enquanto grupo busca modificar a natureza para chegar aos seus fins através das técnicas que ele mesmo inventou e depois lhe foram impostas, sobretudo depois de 1945. Técnica de todo tipo. Assim como dizia Max Sorre, as técnicas não são apenas as técnicas materiais, as técnicas culturais, as técnicas sociais, as técnicas são políticas. São essas técnicas todas que modificam o espaço que são objetos do nosso trabalho, mas a compreensão dela é filosófica. A técnica não tem significação por si mesma, como as coisas não valem por si mesmas. Então a geografia é uma filosofia das técnicas, embora a palavra filosofia seja uma palavra quase obscena no cenário geográfico, então, houve uma série de pessoas que vieram me dizer "você está fazendo mal a disciplina porque está complicando as coisas, botando palavras difíceis”. O difícil faz medo nas pessoas, que se tornaram cômodas, num mundo onde o conformismo se tornou regra geral. Ora, vou propor outra definição, hoje, a geografia é a disciplina que deve se incumbir de estudar o uso do território. Isso tem uma vantagem, uma vez que nós não podemos mandar, por enquanto, mandar para a Faculdade de Ciências os colegas que nos nossos departamentos fazem apenas geografia física. Quem sabe se a gente, levando em conta a noção de uso de território, a gente pode chegar a unir o chamado físico, ao chamado humano e o nexo que é histórico. O histórico pelas realizações já feitas e histórico pelas realizações possíveis. Hoje, não há em nenhum espaço no mundo que se possa chamar de espaço vazio. Isso não existe. Não há nenhum território no mudo o qual se fale como sendo um domínio da geografia física, pelo fato de que ali o homem não por os pés, que o seja, não só apenas pelo fato, pela verdade das ambições internacionais, que se impõem sobre esses territórios chamados vazios, e dos quais, de cuja realidade apenas duas nações são cientes, isto é, os Estados Unidos e a União Soviética são os únicos países que sabem exatamente o que nos detemos, o que todos os outros países têm. Só há dois países no 
mundo capazes de sabê-lo. O território vazio é um território cheio das intenções dos outros. Por conseguinte, não é um território vazio. Ele também pode se encher das nossas intenções. Não é um território vazio. E o chamado natural não é do domínio das Ciências Exatas. Um equívoco dos que imaginam que o natural é do domínio das Ciências Exatas, exatamente porque não há Ciência Exata, na medida em que o conhecimento progride em que a história se faz, novas coisas se descobrem, novos usos são descobertos para elementos que até então pareciam inúteis. Novas possibilidades se criam e toda gente sabe que o possível é muito maior do que o existente, a realidade é pequena diante da possibilidade. Ora, a geografia física para ser útil ao país e para poder enquadrar-se na geografia tout court, tem que rapidamente que levar em conta isso ou então que se mudem para Faculdade de Ciências, rapidamente, também. Eu sei que é difícil porque nas universidades, como todo mundo sabe, as universidades são o grande domínio da crítica e é por isso que onde tem atividade será o último bastião da autocracia desse país, será o ultimo lugar a se democratizar nesse país, pela sua dinâmica interna, que impede qualquer que seja a mudança, ainda que seja pequena. É por isso mesmo que talvez a universidade vá cair e enterrar-se sobre os destroços do edifício que construiu mal e que deseja continuar mal gerindo. Ora, essa universidade desastrosa na qual trabalhamos tem que mudar porque o país mudará sobre o influxo das influências externas e do movimento interno. Aqui, queria também propor uma categoria de analise distinguindo o que chamamos paisagem do que chamamos espaço, são duas coisas diferentes, cuja confusão nos tem custado muito caro. A paisagem é um aspecto da configuração territorial. A configuração territorial é o conjunto das coisas existentes sobre um dado espaço nacional, digamos. A configuração territorial é o pedaço de natureza que cabe a cada estado. A natureza compreendida - como já disse como conjunto de todas as coisas, aquelas que chamamos naturais e que já não são mais aquelas que chamamos artificiais e que desde o momento que existem se tornam naturais.

Ora, a configuração territorial se apresenta aos nossos olhos como paisagem. A paisagem que vejo desta sala é diferente da paisagem que se vê do topo de um edifício, de um avião Cessna ou de um grande avião capaz de subir mais, em altura, de elevar-se mais no chamado céu. Ora, e se a paisagem, um pedaço, um aspecto da configuração territorial, que é apreendido por nosso corpo, um contato com nosso corpo humano com o corpo das coisas existentes, através da nossa capacidade de ver e os meios que nos são dados para ver. A configuração territorial é indivisível e que me valeria comprar um pedaço da Belém-Brasília, ou alguns quilômetros da estrada de ferro que vai de Salvador a Juazeiro para coisa nenhuma. A configuração territorial é um dado que pertence a noção de totalidade, enquanto que a paisagem parte dessa configuração territorial sensível aos nossos olhos, não é, não participa da condição do total; ela é fragmentária e por isso ela nos engana. A paisagem é uma mentira funcional, para compreender o espaço é necessário ir além da paisagem, isso é, ultrapassar aquilo que nos é sensível aos sentidos e dar lugar a elaboração cientifica, isto é, ao reconhecimento 
do que as coisas são dentro de um sistema de coisas que é gerido por um sistema de ações. O espaço é o resultado deste casamento, entre a sociedade funcionando, isto é, das ações, como disse há pouco, é ação e a paisagem. Se transformarem este auditório (Auditório da Reitoria da UnB) numa boate, será uma boate, não mais auditório. O novo uso do espaço, assim como fazemos com as cidades mudando o uso das suas diversas parcelas. Isso é que é espaço, o espaço é o resultado desse matrimônio ou simplesmente outra coisa entre a Sociedade e a configuração territorial e a paisagem. $\mathrm{O}$ espaço é, por conseguinte, não apenas aquilo que fica como coisa imóvel plantada num solo, mas é a sociedade que dá vida a essa coisa.

Portanto, a sociedade evolui, muda através dos tempos os edifícios, as estradas, as construções dos homens perduram mudando de função, na medida em que a sociedade lhes atribui cada dia que passa uma função diferente daquela de ontem. Não o digo de maneira alusiva, mas de maneira concreta e imediata, porque jamais o hoje é igual ao ontem ainda que o transcurso do tempo seja de vinte e quatro horas.

O espaço é nosso domínio e a paisagem também o é. Mas a paisagem apenas como fenômeno, do qual partimos para compreensão das essências, isto é, a ação política, a ação econômica, a ação cultural, a ação moral, que faz de uma coisa hoje o que ela não era ontem e que por isso mesmo pode fazer dela amanhã o que ela não é hoje. O nosso domínio é muito mais de saber o que fazer das coisas amanhã do que de aprender apenas o que as coisas são hoje e eram ontem, o que as coisas são hoje escapam à nossa vontade. A nossa vontade, na medida em que o homem é projeto, pode incidir sobre as coisas atribuindo-lhes uma função nova. É essa geografia que aspiro ver ensinada, praticada nas universidades e fora dela. Porque sem essa geografia jamais deixaremos de ser os profissionais de ordem secundária ou terciária, pagos em consequência disto. E vejam nas universidades o prestígio que é dado ao geógrafo. Vejam o tratamento que é dado nas universidades ao geógrafo mais eminente que seja e que nela venha a se exibir como conferencista. Não é o caso dessa universidade, onde fui extremamente bem recebido, onde continuo sendo extremamente bem tratado espero, continuar sendo bem tratado. Mas os geógrafos são uma espécie de primo distante, longínquo de terceira classe, exatamente porque ele é incapaz de ter a visão integral das coisas que permite conhecer os significados de cada coisa e assim descobrir a intencionalidade secreta dos que fabricam as coisas.

É com essa palavra que termino esta conferencia, esta palestra. Fazendo um voto para que possamos juntos, os que ainda não descobriram isto que imagino ser a verdade, e ser não apenas a minha verdade e que possamos, como intelectuais que somos ou pretendemos ser, ou desejamos ser, capazes de nos abrir sobre um outro caminho. Todos nós fazemos um caminho que é nem sempre retilíneo, linear. A grandeza esta em saber retificar esse caminho, no momento em que a crise pessoal se mostra mais evidente. Ora, as crises das coisas, como é a crise do mundo atual é um momento importante na criação dessas crises pessoais. O meu grande desejo é que essa crise pessoal atinja cada um dos geógrafos e dos planejadores, permitindo repensar o que 
fazem, no sentido da reconstrução da nação brasileira, que tento necessita do nosso trabalho de pensadores, de professores e cidadãos.

Muito obrigado pela tolerância.

Muitas palmas!!

\section{Coordenador Aldo Paviani}

Por solicitação do Professor Milton Santos e, naturalmente, facilitando as coisas, vou abrir o debate aos membros da mesa e, depois, ao público, continuando, evidentemente, à tarde. Passo, portanto, a palavra ao professor Marcos Formiga. Os que, do plenário, desejarem fazer suas intervenções, há um microfone para que sejam ouvidos por todos. A palavra para a intervenção do professor Formiga.

Professor Marcos Formiga:

Pela segunda vez eu corro o vexame para mim de debater Milton Santos. Na primeira vez no Recife, no Seminário sobre a Pobreza Urbana, Milton Santos explodiu com as suas idéias galopantes e conquistou o auditório de forma que os debatedores não tiveram vez. Aqui, certamente não seria diferente. Naquela vez, estava muito em boa companhia de Francisco de Oliveira. Não sei se Milton Santos ainda se lembra de que também concordou em não usar o tempo disponível para o debatedor e deixou que todo o auditório se pronunciasse. Acredito que, como temos três debatedores, vamos tentar ser o mais objetivo e retirar do público a maior parte da participação nessa segunda etapa da palestra de Milton Santos.

Eu estou aqui não como geógrafo, mas fico muito satisfeito em ouvir todas essas acusações feitas a essa profissão que como economista eu tenho a mesma sensação. A economia, diferentemente da geografia, não tem ninguém no país pensando de forma tão crítica como a geografia. Então o papel de Milton Santos no Brasil como geógrafo profissional é extremamente construtivo. Quando a gente quer na economia pôr em discussão ou discordar das verdades e dogmas dos economistas neoclássicos, já que os clássicos hoje são mais história do que economia, a gente se sente muito mal porque nossos colegas nos marginalizam. Não como marginalistas da Escola de Viena. Mas, nos deixam de lado, uma vez que qualquer discordância não merece muito respeito. Os estudantes de economia devem notar que ultimamente têm sido lançados alguns livros nessa linha, o Jacques Attali, por exemplo, a Antieconomia; o Hardy, sobre o que há de errado na economia. Então existe essa mesma sensação de impotência e de desatualidade da teoria econômica na aplicação na aplicação de problemas práticos. O exemplo da realidade econômica brasileira nada mais ilustra, nada mais caracteriza, do 
que o predomínio de economistas monetaristas da Escola de Chicago, tratando de uma realidade que não requer, nem admite esse tipo de solução.

Quando Milton Santos fala da desvalorização da geografia e isso é uma interpretação muito pessoal (minha), portanto enviesada, e de um não profissional da ciência aqui discutida hoje de manhã. Eu tenho a impressão de a aproximação da geografia com as geociências e de forma especial a geologia, foi tremendamente prejudicial para a geografia. Eu tenho a impressão que se a geografia se preocupasse com o homem, quer dizer, fosse mais geografia humana e menos geografia física, ela teria tido uma participação muito mais importante do que até agora tem ocupado. A minha impressão é que, à medida que a geografia ao se aproximar da geociência, e tentando a uma imitação das ciências exatas ou a tentativa disso, foi pouco a pouco perdendo território. Isso é interessante porque na economia é exatamente o contrário, a economia, tida como a mais respeitável das “ciências sociais”, ela se deu muito bem na medida em que ela se aproximava das ciências exatas e o quantitativismo fez com que a economia recebesse um tratamento diferencial e bastante respeitado dentro da comunidade cientifica. É sem dúvida nenhuma, das ciências sociais aquela que tem um maior Ibope. Acredito que esse excesso de quantitativismo foi muito bom no sentido de que o status da ciência econômica melhorou, mas em hora nenhuma esse excesso de preocupações numéricas com a ciência tipicamente social ajudou na resolução de problemas. A verdade é que hoje mesmo os mais quantitativistas, e eu citaria Georgesco que é um matemático por formação e economista profissional, tem dito que o excesso da matemática e do quantitativismo na economia foi mais prejudicial do que benefícios trouxe a essa ciência.

Essa preocupação de Milton Santos com a geopolítica achei tremendamente interessante. Por incrível que pareça, ele aqui não citou, mas, quando trouxe essa preocupação com a geopolítica, me lembrei logo do ministro da Casa Civil da Presidência da República e quão atualizadas são suas preocupações com um livro que eu mesmo desconheço. É livro esgotado, só existe na biblioteca e certamente a necessidade dos geógrafos e dos estudantes de geografia e dos economistas preocupados com o espaço, em tentar ler o livro do ministro Golbery do Couto e Silva. A preocupação da geopolítica faz com que a geografia nem tanto esteja tão desvalorizada como disse Milton Santos, como a mais desvalorizada das ciências sociais, quando tem o ministro mais prestigiado do Brasil. Então, vocês devem aproveitar esse contato com um profissional da área e fazer com o que a geografia seja revalorizada. É um paradoxo, mas extremamente verdadeiro num momento que ele disse que as ciências geográficas estão na pior.

A preocupação de Milton com relação a coisificação da economia e do homem tem na economia um a explicação muito razoável. Em economia, produção e consumo se distanciam muito mais quanto maior for o grau de desenvolvimento. Mas, para raciocinar de forma bem elementar, na sociedade primitiva o índio, o homem primitivo, ia ao rio, pescava para consumir, não existia nenhuma intermediação. Então, era a 
satisfação direta das suas necessidades. Com o desenvolvimento do próprio homem e do uso da tecnologia vão se distanciando essas duas funções básicas da economia, produção e consumo. E, quanto maior for o grau de desenvolvimento envolvido, por exemplo, um carro, vocês não imaginam quanto tempo leva na linha de produção a formação de um carro; não só carro na sua parte mecânica, na sua parte de uso de metais, mas os componentes plásticos, de borracha, e outros, que entram na determinação final daquele produto. O carro exemplifica muito bem como paradoxo do outro lado do exagero tecnológico há o distanciamento entre produção e consumo. Isso faz com que cada vez mais o homem perca um pouco a sua possibilidade de interferência nas coisas no momento que ele passa a ser quase que uma parte mecânica desse processo. Essa coisificação é perfeitamente natural e a economia, talvez mais do que a geografia, é responsável por isso. Quando Milton fez aqui uma alusão critica a obra do Marx, eu me lembrei de que aprendi a dar valor à interpretação, à formação capitalista com o surgimento da cidade, uma obra que certamente todos conhecem que é a Classe Operaria na Inglaterra, de Engels. Foi lá, naquele livro, que vi como o capitalismo se tornou viável graças às cidades. Então, a geografia e a economia, unidas para a viabilidade de um processo econômico, que ainda hoje, selvagem como é, está vigorando. (...)

(Lado “B”da Fita número 2).

Tal qual, Mackinder, citado quanto à divisão da África ou do Oriente, Marx também não foi diferente. Ele propunha para a Índia e o Marx foi tremendamente falho na interpretação dos países subdesenvolvidos. Não existia grande preocupação naquela época por esse tipo de coisa. Mas, ele achava que uma forma de viabilizar a Índia era uma exploração forte por parte da Inglaterra. Os antimarxistas gostam e adoram essa posição do Marx, porque vão encontrar lá um ponto frágil em toda a sua filosofia em toda a sua argumentação. Novamente, aí, um paradoxo: Marx admitindo que, para viabilizar a Índia, era necessário um processo de colonização. Então, nem Marx se livrou desse fenômeno, aqui tão deprimente ilustrado que foi o colonialismo.

Uma outra preocupação, talvez a ultima, e vocês devem ter notado que eu tentei algumas pílulas sobre a argumentação de Milton Santos, é que Milton fala de um problema de espaço vazio e descontinuidade. Por mais organizado o espaço, por mais planejamento que haja, e essa tendência hoje de se procurar fazer com que o planejamento não seja apenas uma técnica, mas um instrumento para viabilização da ocupação humana, eu não tenho muitas ilusões de que essa descontinuidade vai continuar. Vai continuar porque com as forças econômicas em funcionamento, o desequilíbrio é sempre consequência. A prova é que o processo de desenvolvimento, em sua natureza, ele é desequilibrante, e ele é desequilibrante exatamente no momento em que forma pólos, forma módulos e forma centros. Por mais preocupados que estejam os planejadores, e nessa união de geógrafos e economistas, o máximo que podem fazer é 
minimizar essas tentativas de aglomeração, mas eu não creio e não tenho nenhuma visão prospectiva de como será possível esse tipo de modificação na organização do espaço.

Então, fico por aqui e passo a palavra a um novo debatedor, esperando que a polêmica em si venha a partir do povo. Muito obrigado pela atenção.

Obs.: Toma a palavra o estudante Saint Clair Versiani, que sem usar o microfone, tornou inaudível sua manifestação.

Coordenador Aldo Paviani:

Pergunto então se alguém deseja fazer uso do microfone para se dirigir ao Professor Milton Santos a sua indagação?

Fala Azize Drumond:

Bem, eu preferia ter falado lá do meu cantinho, mas já que me forçaram a ocupar esse espaço, aqui estou. Eu não vim praticamente fazer nenhum pergunta ao Milton Santos, quem sou eu? E quero dizer antes das minhas palavras que desde meados 64, 65 eu já aprendi a gostar de Milton Santos, quando estava em Portugal era aluna de Orlando Ribeiro. De lá sabíamos as suas notícias pelas suas andanças por Paris ou por outros países da Europa. Então, aprecio Milton Santos. Não preciso dizer que isso é uma verdade. Adoto seus livros e apregôo seus livros. Adoto os livros na universidade, apesar da crítica dele sobre os livros estrangeiros que adotamos. Não temos uma meia dúzia de Milton Santos para fabricar mais livros para o Brasil. Mas, aqui também eu quero lhe dizer da liberdade que eu sinto em dizer o que estou dizendo. Eu achei a palestra de Milton Santos, como ele próprio disse seu discurso, um tanto amargo, um tanto triste. Assim me pareceu; estou dizendo por mim. Achei que talvez os anos de exílio o fizeram uma pessoas ressentida e triste. Achei bastante pessimista a sua palavra. Então, quero deixar, aqui, que realmente existe muito de bom, muito de grande, muito de otimismo, dentro daquilo que a gente conceitua como geografia, como Brasil. como espaço, como política brasileira. Quero dizer que Milton Santos que falou com tanta liberdade, com tanta sinceridade, falou dentro de uma universidade.

Milton Santos:

Olha, eu devia fazer respostas conjuntas, mas eu não tenho nenhuma vergonha de ser emotivo, pelo contrário eu acho que na medida em que a gente recusa ser emotivo, recusa ser um homem. Eu quero ser um homem inteiro. Sendo um homem inteiro, eu quero também ter graves defeitos. Só que não há defeitos. Os homens têm atributos. Defeitos e qualidades num julgamento, que se portam as pessoas. A tristeza que pode ter transparecido na minha palavra, é sobretudo aquela de não poder no país em que nasci, e desejo viver e morrer, trabalhar decentemente. (Nesse momento Milton vai às lágrimas) O trabalho que me oferecem nesse país... (Continua fortemente emocionado) é indecente. As portas das universidades, inclusive desta, me foram fechadas. Não sei se a colega sabe disto. Fui proposto por um professor para esta universidade, enquanto 
ensinava em Columbia. Fui recusado, fui recusado pela universidade onde criei o instituto de geografia. (Forte emoção embarga sua voz. Chora e lacrimeja. Ele é consolado pelo coordenador, professor Aldo Paviani, e o auditório irrompe em demoradas palmas). Fui recusado em Presidente Prudente, num concurso aberto publicamente. Em São Paulo, fui recusado. Sou professor visitante no meu próprio país!! Eu tenho o direito de ser amargo. Mas não perdi a esperança e espero que possa ser muito útil ao meu país. E eu serei!! Muitas palmas.

\section{Professor Mário Tomelin}

Professor Milton Santos: sem conhecer o que o senhor ia falar nessas palavras e que realmente o senhor motivou o auditório, queria cumprimentá-lo pela sua brasilidade de retornar ao Brasil. Todos os brasileiros conhecem, ou principalmente se dedicam um pouco à arte, talvez, de ensinar que é uma arte, conhecem de suas andanças pelo mundo. Sei que o senhor esteve nos organismos internacionais. O senhor esteve na UNESCO. O senhor esteve ensinando em universidades africanas, Nairóbi e outras e o senhor aqui, então, com esse esforço de brasileiro, o senhor se predispôs a, talvez, não passar vexame, mas mostrar que ele é mais brasileiro ainda, de querer vir aqui e se submeter a este constrangimento de ser recusado pelas universidades brasileiras. Então eu dou meus parabéns porque o senhor é mais brasileiro do que todos os brasileiros que o recusaram. Parabéns realmente! (Palmas)

Como pergunta que eu queria lhe fazer, dentro desta maravilhosa posição que o senhor levanta, o senhor saiba que a sua disciplina, como geógrafo, ou melhor, sua área, atinge a todos os conhecimentos. Nós do Departamento de Administração, usamos seu livro para ensinar Administração Municipal, para ver a identidade do homem com o local. Nós começamos de lá, usando seus livros, Sociedade e Poder, por exemplo, entre outros, lhe perguntaria se essa visão que o senhor tem, muito bem colocada de espaço vazio, que como o senhor falou que espaço é vazio para quem olha ou para quem não sabe enxergar; eu lhe perguntaria, dentro de uma visão geopolítica, como é que o senhor veria esse espaço vazio considerado pelo poder político brasileiro dento do aspecto do federalismo brasileiro. Porque nós somos uma república federativa apenas copiada, mas ela não é exercida na pratica, nos não somos uma verdadeira federação, principalmente em função do centralismo que é exercido pelo poder central. Então, diante desse fato, eu queria saber como o poder político poderia enxergar esse espaço que para ele é vazio, mas é pleno, é cheio, e que poderia suprir esse vazio dando identidade própria a esse federalismo a nível local, porque é a nível local que nos começamos a identificar o homem porque é lá que ele nasce, é lá que ele vive. Dentro dessa perspectiva, que historicamente foi construído (esse espaço) para um federalismo igualitário - e que na verdade essa igualdade é prejudicial, porque um poder central pode emitir uma simples portaria ou um simples decreto para atender desde o Amazonas ao Chuí e isso é prejudicial à identidade local. Então, eu gostaria de saber como poderíamos, aos poucos, 
tentar fazer esse Estado considerar o espaço vazio que ele o vê, apesar de estar cheio. Muito obrigado. (Palmas)

\section{Prof. Milton Santos:}

Bom, eu vou dar a resposta, agora, a meu amigo Formiga. Amigo, criado pelo trabalho, através do trabalho. A nossa estima se criou pelo fato de que ambos, apesar de termos visões diferente do mundo e desse país em que vivemos e onde temos o direito ou devemos buscar os meios de exprimir nosso pensamento. Isso nos aproximou muito, também pelo fato de que discordamos, a discordância também aproxima as pessoas. A coisificação é um dado da economia, mas a economia forneceu para o planejamento do capital apenas algo ideológico. É minha impressão. Quem forneceu o instrumental para que o capital, a estrutura do capital internacional pudesse ocupar os espaços foram as ciências geográficas. As ciências geográficas, o planejamento, inclusive, sempre foram instrumentais a isso, e como que a economia neoclássica ela é unicamente o ideológico e é por isso mesmo que no mundo do discurso os economistas tem uma ressonância maior nesse discurso ideológico que permite a aceitação das ações. Essas ações são, antes do mais, geográficas para a realização das finalidades de um país ou de outros países nele é o geográfico que comanda a realização. A invasão do território do capital estrangeiro ou pelo grande capital nacional é a geografia que separa deliberadamente os homens como nesta cidade, onde há separação dos pobres e dos ricos. Não é apenas um dado da economia, é um dado da política, isto é, as decisões que foram tomadas, por exemplo, em 1966, de segregação dos pobres dentro dessa cidade, isto é, de uso particular do território urbano são do domínio do espaço. Do estudo do espaço global que estou sugerindo. Também creio que o desequilíbrio sempre haverá, inclusive acredito que quando alcançarmos o socialismo que vamos construir nesse país. Esse país não escapará como de mais a construção socialista. Evidentemente, será um socialismo brasileiro - haverá também desequilíbrios regionais. O problema é o uso que se faz desse desequilíbrio regional. Desequilíbrio regional pode ser usado para que uma classe se perpetue no poder ou uma facção de classe, um segmento de classe. Ele pode ser utilizado para que as populações sejam atendidas. Aí é exatamente o meu ponto, quer dizer, não é a questão formal que a gente tem que se preocupar. Estamos de acordo nisso: o desequilíbrio regional vai se tornar mais exigido ainda se alcançarmos essa nova etapa da historia nacional, isso é a etapa em que as populações possam ser atendidas. A questão não é o desequilíbrio regional, mas o que vamos fazer dela. Quanto a Marx eu não pretendi faze-lhe uma crítica atemporal, quer dizer que toda crítica tem que ser colocada no tempo em que o cidadão escreveu. Apenas me coloquei, digamos assim, dentro daquela sugestão feita por Marx: se você quer ser marxista, não seja marxista, isso é, você não deve me seguir você deve partir do real e tentar descobrir as correlações entre o real, que a realidade nunca aparece isolada de outra realidade é a palavra de um grande filosofo e político que é desconhecido do Brasil. Exatamente porque não nos preocupamos com a distribuição das ideias de africanos. Imagine 
distribuir nas universidades ideias africanas. O senhor Amílcar Cabral que nos ensina, nos ensinava porque foi assassinado justamente por ter amor por seu país e exprimi-lo. Ele dizia: a realidade está sempre em relação com outra realidade, mas há uma hierarquia de realidades, então essa descoberta da hierarquia da realidade que nos conduz a compreensão do que se está fazendo e de intervir seja para fazê-la, se temos poder, seja para propor coisas. Aí chegamos ao fato de que o general Golbery do Couto e Silva, geógrafo eminente, cujos livros leio com o apreço que merece o intelectual, seja um homem prestigiado, embora o geógrafo não o seja, é por aquilo que falei no começo, é que o general Golbery dispõe de informações que ele com seu reconhecido gênio organiza e nós não temos informações nenhuma. A nossa indigência, em matéria de desinformação, é grande e a universidade é um deserto de informação, onde os livros brigam com os livros e às vezes os conceitos brigam com os conceitos. Nos deixamos arrastar por essa discussão inócua, vazia, que nos faz perder tempo e perder inclusive o caminho. Ainda somos empurrados, às vezes, pelas manobras dos institutos que distribuem o dinheiro para a pesquisa, que reduzindo as verbas outorgadas a certos centros, estimulam as rivalidades. E a gente embarca na luta pessoal pela conquista do dinheiro da pesquisa que é o grande corruptor da universidade. Não esqueçam isso: o dinheiro das pesquisas contribui para corromper, através dele os estudantes, e não há corruptor que não se corrompa. A universidade brasileira é o grande lugar da corrupção em grande parte pela maneira pela qual as verbas das pesquisas são distribuídas, de fora dela. Quanto ao que diz o Mário Tomelin, como considero o poder político na questão do espaço vazio. Ora, eu disse também que esses satélites que estão aí girando todos os dias e que pagam as bandeiras da União Soviética e dos Estados Unidos e de cujas fotografias nos chegam os sobejos que alegremente trabalhamos como se fossem um grande instrumento de trabalho e que são trabalhadas de maneira efetiva pelos geógrafos americanos e pelos geógrafos russos. Não esquecer que, em 1956, quando no Congresso Internacional e o governo de então proibia, hesitava em admitir a presença dos russos no Brasil. Eles chegaram ao Brasil com uma exposição de mapas do Brasil, que fizeram inveja aos colegas do IBGE. Ora, na medida em que nós não dispomos dessas informações, todos os que decidimos, e é o que está sendo feito no Brasil, ocupar o espaço todo. O que é a conquista da Amazônia, que está na terceira etapa da organização do território, prevista pelo geógrafo Golbery. Essa terceira etapa corresponde exatamente ao uso pela nação brasileira do território brasileiro, ainda que esse uso tenha que ser feito sobre as condições da economia internacional de hoje, isto é, sobre as formas mais modernas que incluem a presença das multinacionais. Mas, aí converge, como tudo hoje está convergindo, isto é, as contradições que hoje se mostram ainda maiores. Se de um lado o estado brasileiro pensa em permanecer, estar nesta área vazia, não deixá-la vazia para exercer nela sua soberania, historicamente está obrigado a aceitar a presença do mais moderno que inclui as multinacionais, que trazem coisas. Mas, as coisas tem a função que lhes atribuímos, quer dizer que isso não me assusta muito, na medida em que creio na história. 
Quanto ao federalismo e o nível local, ainda aí é um fenômeno de pacto nacional. O que está se passando é que a federação acumulou poderes para ficar, para poder marchar pari passu com o desenvolvimento da economia internacional. Não se podia conceber um país que decidiu participar do pacto internacional do lado do capitalismo que esse país, ao decidir-se também, agrupar as possibilidades de inversão que viabilizam o capitalismo em mãos de poucas pessoas. Não podia ser deixado a uma decisão que reunisse vice-governadores, a maior parte dos quais não tem muita noção do que estão fazendo, não tem muita noção do que é o espaço em que estão governando, porque, do contrário, isso impediria a rapidez das decisões que exige a economia internacional. Só que esse fenômeno está trazendo consigo a desculturalização do Brasil. Não esquecer que a influência norte-americana ela não apenas, não consegue desgraçadamente transferir o que chamaria de cultura norte-americana aos países invadidos, entre os quais o nosso. Ela simplesmente suprime a cultura, ela desculturaliza. E é o que esta se passando no Brasil. Ora, a reculturalização do Brasil que vai ser exigida pelas necessidades da população, que vai exigir um novo pacto territorial, uma nova organização do território brasileiro, talvez uma nova forma de distribuir os impostos, uma nova forma de distribuir o poder, uma nova forma de distribuir todos os recursos nacionais, passa por uma reforma dessa federação, por uma reculturalização de um país que se desculturaliza, que esta ameaçado a ser povoado por ninguéns. O exercício da democracia ele próprio vai exigir que a proximidade do poder se faça em relação aos indivíduos e naturalmente um novo pacto territorial se está preparando. Ele se está preparando, mas não sei se está preparando de forma estrutural ou funcional. Nós temos o dever de participar da elaboração desse pacto ainda que nossa voz não seja reconhecida inteiramente, mas na medida em que emitamos essa voz e que nos deixem falar. Aí, eu vou de novo responder a colega Azize Drumond: não basta me deixar falar na universidade, uma das minhas grandes frustrações são os aplausos, que eu levo pra casa, enquanto ainda não tenho os instrumentos de trabalho.

O discurso do intelectual que se opõe ao regime é ainda uma manobra de despistamento, porque ele, na medida em que lhe são recusados os meios de trabalhar. Formiga é testemunha disto, não quero fazer meu autoelogio, mas sou um pesquisador formado, sou um professor competente, sou um geógrafo que sabe o que está fazendo e o Conselho Nacional de Pesquisa, numa chicana inadmissível, incorreta, indecente, me pede a mim, que formo professores, que formei professores, que explique melhor porque quero fazer tal ou qual pesquisa, isto é, que adianta fazer esse discurso que vai ser digerido rapidamente, por isso disse no começo que me fazem medo nas assembléias, que me fazem medo os aplausos, se a mim não me dão os recursos para trabalhar para meu país. Será que o país não tem pessoas inteligentes bastante para utilizar da maneira que quiserem o trabalho que eu por ventura faça contra suas ideias. Ora, de qualquer maneira, terão que nos solicitar trabalho, que nos dar trabalho, a todos nós, seja o que for o que pensemos porque o país está indo para um novo pacto social e comporta um novo pacto territorial, cuja elaboração não será obra exclusiva de um 
homem, mas de um conjunto de homens pensando diferentemente, ainda que aqui as soluções definitivas sejam do poder.

Coordenador Aldo Paviani:

Passarei a palavra ao debatedor seguinte, Dilma Seli Pena.

Dilma Seli Pena:

Um novo pacto social que está a sendo exigido no país e no mundo. Um pacto social em que o humano seja privilegiado e que as ações do homem, a vida do homem, o bem estar social e pessoal, sejam privilegiados. Como isso se fará? Não sei. Eu acho que aí entra a mensagem primeira do professor Milton Santos, que é a compreensão da realidade, a compreensão da totalidade da realidade. Essa compreensão da totalidade, acho que hoje está um tanto quanto bitolada. Nós sempre caímos no entendimento da revolução industrial, a partir da revolução industrial e ficamos aí. O trabalho do geógrafo em todos os pactos territoriais que o professor falou, realmente é um trabalho a posteriori. Como nós geógrafos podemos trabalhar num novo pacto territorial, social e uma nova mensagem de final de século, essa é a minha preocupação sem querer me colocar apenas no rol dos preocupados e o debate, essa mensagem, apesar de amarga, mas cheia de esperança eu quero tirar daqui.

Então, nessa linha, pediria ao professor que se não fosse por demais cansativo: como o senhor veria as formações econômico-sociais que os seus livros explanam, e o pacto social que deve ser urdido, que deve ser feito, e as suas alterações no espaço. Porque, veja, o espaço que hoje se constrói é um espaço do passado, não é mesmo? Quer dizer, se nós trabalhamos no hoje, nós estamos trabalhando já para o passado. Evidentemente que a nossa preocupação é uma preocupação de futuro, como trabalhar para uma sociedade mais justa. Acho que não tem outra palavra, uma sociedade mais homogênea em que a população seja o objeto de trabalho. O planejamento onde eu estou colocada hoje, onde é o meu campo de atuação, as teorias de planejamento, o ato de planejar, o produto de planejamento é um produto funcional, é um ato funcional, as estruturas são entendidas às vezes, mas elas não são mexidas nunca.

Nesse novo pacto social, evidentemente, um novo pacto social que inclui o espaço, requer profundas alterações estruturais. A partir de que variáveis poderia se pensar, não atuar no momento, ou, quem sabe, pensar e atuar conjuntamente se houver chance e brechas possíveis. Então, é nessa linha, que eu coloco minhas preocupações atuais, a partir de sua mensagem, que me é muito válida.

Professor Milton Santos:

Eu pediria se alguém quer fazer perguntas que o faça na mesma direção. 
Bom, um país, seja qual for o momento da sua evolução, é objeto de um projeto, um projeto que abrange a totalidade dos aspectos da vida social, e é para isso que os partidos existem. Mas, os partidos existem? Estamos numa universidade, sem dúvida nenhuma, qual foi o partido que propôs a forma de sair desses escombros que apesar da aparência do novo e do brilhante, são escombros. Qual foi o partido que propôs isso? Estamos diante da população pobre e as pessoas dizem que governo e oposição vão acabar com a pobreza, mas como? Quem propôs? Em quanto tempo? Não há projeto político quando não se fala no tempo em que se vai fazer.

Fui convidado a falar com um eminente político, coisa que não me agrada muito, mas fiz por solicitação de um amigo pessoal, a quem não podia recusar que está aqui, presente, aliás; não o político, mas o amigo, e que me perguntou a opinião que tinha do programa do seu partido, eu disse: mas que programa? Os senhores não fizeram programa nenhum. Os senhores não nos dizem em quanto tempo querem fazer aquilo e aquilo outro. Então, não há programa. Eu quero que o salário mínimo seja decente, isto é, que hoje o salário mínimo decente seria vinte mil cruzeiros, mas em quanto tempo? Em seis meses? Seis anos? Ou seiscentos anos. Ora, há dois lugares onde o pensamento da coisa, digamos assim, conjunta, total se pode fazer; um desses lugares são os partidos, quando eles são realmente partidos; outro desses lugares é a universidade, quando ela é realmente universidade. Porque o intelectual, no seu trabalho, necessita de um horizonte e ele é tanto mais motivado por seu trabalho quando esse horizonte aparece com algumas possibilidades, alguma expectativa de realização ou pelo menos com luta concreta e não adianta discurso. Vão à universidade na Venezuela, onde costumo ir todos os anos, pelo menos uma vez, onde o governo financia sem receios os centros que se lhe opõem inclusive aquele em que trabalho com mais frequência, e que é dirigido por um senador de um partido que se chama MAS (Movimento ao Socialismo), financiado com amplas verbas do Estado que, por sua vez, me financia nas minhas viagens de consulta, de trabalho, que fazem e no qual o território é contemplado. Então, esse trabalho dos pesquisadores, dos geógrafos, dos sociólogos, dos psicólogos, do demógrafo pode convergir naquele intelectual coletivo de que chamava Gandhi, na medida em que há um objetivo a alcançar. Se esse objetivo não é claramente exposto o trabalho intelectual corre o risco de se transformar num discurso vazio. Risco que corremos nesse país inclusive os que se consideram e são, os que consideram e não são, os que são e não se consideram progressistas. Quer dizer, que a existência de uma vida partidária real é fundamental a que esses projetos, na realidade esses projetos, porque não há um futuro, repito, há muitos futuros, só o que o une ao passado, isto é, o presente porque se coloca no domínio das coisas já concluídas, já feitas e irreversíveis. O futuro são muitos, por isso é que os partidos devem ser muitos e aí os intelectuais, não falo professor porque professor não tem que obrigatoriamente ser intelectual, ao contrário o professor é cada vez menos intelectual, poderão realmente chegar a este. Ora, as formações sociais e o novo pacto social. Todo mundo sabe que uma formação social é sucedida de uma outra formação social, exceto na fase de transição, quando nos temos uma briga entre o capitalismo e o socialismo na fase de transição onde temos, digamos, 
um desenvolvimento das forças emanadas do Estado inclusive dos aspectos econômicos, sociais, culturais e morais numa direção e a persistência do capitalismo; quer dizer, a tradição não é uma formação social mas é um momento de luta entre duas tendências que continuam, que crescem paralelamente. Recado que estou dando aqueles que imaginam que se passa diretamente da democracia ao socialismo. Ora, isso exige também estudo. Não se pode pretender mudar a situação do país sem estudos bastante aprofundados que abranjam toda essa coisa e que a universidade poderia propiciar, se fosse um fórum. Na verdade, não é um fórum permanente. A universidade é um lugar de eventos, assim como este, esporádicos, fazendo uma semana de geógrafos. então trazemos algumas "vedetes" que fazem os seus discursos e vão embora... e acabou, estamos todos contentes. Quando o trabalho é o de dia-a-dia o da elaboração de um projeto, na verdade vários projetos porque a universidade tem que ser aberta a todo mundo, de país. E se faz? Tanto não se faz que vocês do CNPU tiveram que pedir a alguns colegas estrangeiros que viessem para cá. Que primeiro passassem um ano aprendendo português e depois passassem um ano aprendendo Brasil e depois escrevessem uma porção de bobageiras que o próprio CNPU teve vergonha de publicar e fossem embora, enquanto a oportunidade foi fechada aos geógrafos brasileiros. Então, menina, me permita chamá-la assim uma forma carinhosa de me aproximar de você, da senhora. Eu penso que o que a gente tem que fazer é lutar porque essas coisas aconteçam. Lutar por uma universidade que seja uma universidade, isto é, que não seja um lugar que seja dirigido por pessoas invisíveis como são os reitores. Os reitores são pessoas invisíveis. Eu sugeri a um reitor que encontrei casualmente num almoço, onde fui casualmente convidado, que ele pelo menos, que ele fosse comer nos restaurantes da universidade, primeiro porque ele teria as dores de barriga que a gente tem, e segundo porque ele veria outras pessoas, senão aquelas que eles nomeiam. Imaginem: os reitores só conversam com as pessoas que eles próprios nomeiam. O que faz com que eles não saibam coisa nenhum da universidade que dirigem. Vocês já viram o reitor no restaurante? Pois, vocês sabem quem é o homem que dirige a política internacional dos Estados Unidos? Meu colega, em Columbia University, onde tive, não vou dizer a honra, porque não é honra nenhuma ensinar nesse universo, sou um geógrafo competente, me parece que foi uma coisa normal ensinar nela. Eu vi esse cidadão na mesa ao lado da que eu comia, como que se chama mesmo esse cidadão que dirige a política externa dos Estados Unidos atualmente? Brezynsky. Pois é, mas aos reitores lhes parece que a universidade é uma coisa que não é feita de estudantes, de funcionários e de professores. Essa é uma das impossibilidades de mudança: o fato de que os reitores são fantasmas, pessoas invisíveis muito mais preocupados com o serviço do poder do que com o serviço da universidade.

Peço para que alguém transmita ao reitor dessa universidade esse meu recado. E que ele passe a almoçar com frequência nos restaurantes, inclusive o da geografia, onde vocês terão a oportunidade de tentar convencê-lo a dar mais recursos. Esses recursos que são dados, por exemplo, pra trazer aqui o senhor Galbraith, certas múmias, certas 
personalidades que pertencem à arqueologia e que também convide geógrafos, pessoas com pensamento novo, que em vez da atividade puramente promocional que haja uma atividade igualmente séria, cotidiana.

Coordenador Aldo Paviani

Obrigado professor Milton, é a vez da platéia, por favor.

Saint Clair Versiani:

Inicialmente, queria agradecer ao professor Milton Santos, porque foi, realmente, um estímulo a gente poder ouvi-lo aqui. Ainda mais quando foi tocado, aqui, na sua tristeza. Mas, essa tristeza para nos alunos que a gente vê nele, essa tristeza que mesmo de ter sido cassado, ter sido oprimido até hoje e está lutando por uma geografia nova, uma geografia que propõe mudanças; não a geografia que vemos hoje nessa universidade, uma geografia que nos leva praticamente a nada, que nos dá noções vagas, totalmente vazias, não mostra nada para gente. Como que a gente vai poder fazer alguma coisa que já se discutiu aqui, um pacto social.

O professor Milton Santos colocou muito bem, como que vamos chegar a um pacto social numa universidade como essa? Então, acho que essa força que ele nos está dando, hoje, aqui, para muitos alunos que estão entrando agora, aqui na universidade, devem ver. Foi o objetivo que nós alunos convidamos o professor Milton Santos, já no Rio no congresso da AGB para vir aqui para mostrar que a geografia não é só essa que vemos hoje na universidade e nos livros que existe uma nova proposta de geografia. É dentro dessa visão que devemos tentar mudar alguma coisa. Mas, tenho uma preocupação que já foi levantada aqui e já está se tornando rotina. A todos os palestrantes eu faço a mesma pergunta. É uma preocupação minha, que é sobre a prática social, que me deixou assim, também já está até chato falar em Castells que eu também sempre falo de Castells (e tem muita gente que já levantou). Mas, naquele livro dele, quando ele levanta o problema, ele faz uma análise dos movimentos 'citadinos' na Espanha. Então, vejo assim como uma alternativa de chegar a esse pacto social, a partir da prática social. Aí, acho também que entra também a função de nós geógrafos começar já a dar assistência às associações de bairros, associações de moradores, a todo tipo de associações para que a partir dessa forma, dessa prática social, podemos chegar a um pacto social, não só dentro da universidade. É muito importante que se desenvolva também na universidade. Mas, nós temos que ir para fora, porque eu acho que lá fora é que está também a base para se chegar nesse pacto social. Então é essa a pergunta que eu queria colocar para o senhor.

\section{Professor Milton Santos:}

Olha, eu devo dizer que eu ainda estou fazendo minha cabeça sobre as associações de bairros, não tenho ainda uma resposta. Tenho, todavia, o medo de que elas possam patrocinar os egoísmos de bairros. Isso me assusta um pouco. Quer dizer que o bairro, 
na medida em que a geografia não... (uma pergunta entre parêntese: qual é o ultimo livro ou artigo que fala sobre uma cidade toda, no Brasil, que estuda s cidade em conjunto? Alguém me cita um estudo?) Bom, em 1950? Então, nós não conhecemos a cidade como um todo. Então, e acidade é um todo, embora um todo menor dentro de um todo maior que é a famosa formação social. Na medida em que o poder não se distribui igualmente, uma associação de bairro como a que tem perto da minha casa, chamada Alma (Associação Lauro Müller e Adjacências), não terá jamais um poder que tem a associação que é animada pela nossa estimada e competente colega Lysia Bernardes, que é a Associação de Bairro das Laranjeiras, é outra coisa não é? Então, esses egoísmos de bairro vão desemborcar no exercício do poder de influir junto às autoridades competentes, chamadas competentes, que é diferente. Mas, eu apenas estou dando uma respostinha a você porque na verdade não estudei o assunto em detalhe e a gente na universidade deve também ser capaz de dizer, eu não sei isso, não é? Eu não tenho nenhum risco de ser rebaixado na minha posição porque não tenho nenhuma. Então, não há nenhum perigo em dizer que não sei as coisas.

Coordenador Aldo Paviani

Obrigado professor Milton Santos. Passarei a palavra para o professor Ricardo Farret para sua intervenção.

\section{Professor Ricardo Farret:}

Eu vou ser muito breve e levantar apenas um problema, uma observação, em relação ao que o Professor Milton Santos falou.

Todo esse descontentamento, que o Professor Milton Santos manifestou em relação à geografia, eu multiplicaria por " $n$ " na área, quando tratando da área a que eu pertenço que é a área de planejamento urbano. Porque se a análise estática da geografia, que o Professor Milton Santos se referiu, uma geografia preocupada com formas e talvez muito pouco com processo, se gera esse tipo de visão distorcida da realidade, eu perguntaria ao Professor Milton Santos e o faria como observação: o estado de penúria que se encontra a área de planejamento urbano quando ele propõe exatamente intervir nessa realidade que é mal conhecida que é mal interpretada. Durante muito tempo os planejadores físicos, simplesmente através do traço se atribuíam o direito mágico de organizar melhor esse espaço, fazer com que as pessoas vivessem melhor. $\mathrm{O}$ quadro urbano brasileiro está ai, não precisa dar muitos exemplos para perceber isso. O caso de Brasília, concretamente, a cidade toda nascida de um traço, mas totalmente alienado da realidade brasileira, inclusive da realidade prospectiva, quando projetada completamente desvinculada do que viria a ocorrer no Brasil. Durante muito tempo as ciências sociais particularmente a geografia e a economia, serviram de subsídios. A 
análise da geografia, a análise da economia foram subsídios se não exclusivos, pelo menos os mais importantes para o planejador urbano. Ora, se esses subsídios vinham distorcidos da realidade, vinham distorcidos, vinham deformados, é lógico que o produto final só poderia resultar num produto também deformado. Durante muito tempo, nós da área de planejamento urbano, nos preocupamos exatamente com o que levantei anteriormente, com essa intenção de organizar o espaço, como se o espaço fosse um jogo de armar, que pudesse ser armado independentemente das categorias sociais que deles vão fazer uso.

Me refiro mais especificamente, e esse é um ponto que gostaria de ver o professor Milton Santos, talvez, no debate da tarde, pudesse desenvolver alguma coisa, ao espaço interno da cidade. Como é que esses mecanismos que ele magistralmente colocou na escala macro, na escala internacional e na escala nacional por desigualdade e desnível, como que isso repercute, como isso acontece no espaço urbano. Esse tipo de enfoque, eu diria, que foi a grande contribuição da análise marxista recente em termos da estrutura interna da cidade.

Durante muito tempo, os marxistas não enfocaram a estrutura interna da cidade. Era considerada como um dado, não sei se sem importância, mas um dado secundário no estudo do fenômeno urbano. Foi preciso o renascimento, a reinterpretação do conceito de renda fundiária de Marx e sua aplicação para a estrutura urbana que levou, eu diria, felizmente a todo esse corpo analítico que permite hoje uma visão mais clara da estrutura interna da cidade. Como já solicitei, acho que o professor Milton Santos vai ter a oportunidade de, talvez no período da tarde, desenvolver um pouco mais esse aspecto. Mas, chamaria a atenção para um ponto que ele levantou de que o Estado como um dado fundamental na realização do capital. Diria que na estrutura interna da cidade, esse fenômeno ocorre também e, talvez com clareza mais visível do que na escala da sociedade como um todo. Há os chamados bens de consumo coletivos, hoje, uma atribuição inalienável do Estado nada mais são do que mecanismos criados para facilitar a reprodução do capital dentro da estrutura urbana. Então, pediria ao professor Milton Santos, gostaria de ouvir uma palavra, uma palavrinha sobre isso, se não agora pelo menos no período da tarde, com mais clareza, sobre esses mecanismos que eu apenas estou colocando como um esboço. Essa é a tendência eu diria que os planejadores urbanos hoje vêm a cidade muito menos como essa renovação que o professor Milton Santos reivindica para a geografia eu diria que é o que os planejadores urbanos mais conscientes reivindicam para o planejamento urbano. É um entendimento do urbano menos como um fato físico, um fato material, mas como um fato em que processos, grupos de interesses, classes sociais se digladiam no sentido de apropriação da riqueza como no âmbito da economia como um todo. Nesse sentido, acho que a pergunta, a questão que você levantou sobre os movimentos sociais de bairro, que o professor Milton Santos levanta a dúvida, que eu acho pertinente, em relação a validade desses movimentos. Isso me reforçou um ponto que tenho notado no Brasil é de que o surgimento desses movimentos como solução, como uma resposta a todos esses elementos de estruturação do espaço urbano que são muito mais do que um dado 
eminentemente físico. A estruturação do espaço urbano da maneira que eu estou colocando, se refere às atividades, ao uso desse espaço, ao domínio desse espaço, por parte da própria sociedade. Levanto o mesmo tipo de questão levantada pelo professor Milton Santos, que a meu parecer, são movimentos de classe média e que entraram ofuscando, eu diria, o verdadeiro cerne do problema da apropriação do espaço urbano da sociedade como um todo. Acho que fica um movimento reivindicatório, mas eu acho que o caminho de uma sociedade que esteve trancada durante período bastante longo como o nosso, eu vejo nisso um dado altamente positivo, mas não acho que o caminho de apropriação, de retomada, reconquista do espaço pela população esteja por aí.

Eu gostaria de ouvir então, professor, e para encerrar, mesmo essas questões por mim levantadas se tornam de certa forma irrelevantes quando ouvimos hoje, aqui, dados, afirmações, argumentos, mostrando essas grandes contradições como, por exemplo, o professor Milton Santos - professor visitante em seu próprio país - e a alienação da universidade em relação a esses problemas que estão aí nos afligindo. Então, acho que se a discussão tiver que ser substancial, ela tem que se concentrar talvez fora dessas tecnalidades que eu tentei levantar e se concentrar nas grandes questões que mostram essas contradições que eu levantei.

Professor Milton Santos: (mudança de fita, de numero 3)

Ao atender a pergunta, vou logo lhe adiantar uma coisa: a geografia urbana não é mais possível. Isso exige uma economia política da cidade. A geografia urbana não pode ser mais uma resposta à compreensão do todo urbano. Só através da economia política da cidade, isto é, vou, quem sabe, até entrar em detalhes importantes, essa tarde, se me for dado o tempo e se a minha imaginação continuar funcionando de tarde. Mas, penso que a impotência dos planejadores será sempre maior do que a dos geógrafos porque os planejadores não planejam coisa nenhuma, isso é uma ilusão. Quando por exemplo, se decide fazer, como no Brasil atual, a abertura do campo ao capital. Isso tem um imediato reflexo na vida urbana e quem é que decide é o ministério da urbanização ou é outro ministério? Quando se decide criar no Brasil cinco milhões de casas, isto é, a população que tem apenas alguns países no mundo e a sua localização não é objeto de consulta a nenhuma espécie de planejador, é resultado de uma decisão de um ministro que não é o do planejamento e nem o da urbanização, o que, que as pessoas podem fazer? Quando se decide conquistar a metade maior do país e transformá-la, que é um imperativo territorial, que é um imperativo nacional, a conquista da Amazônia. Isso vai alterar completamente a organização das cidades como sistema e a organização interna das cidades. Sobre isso aí não foram consultados, nem vão ser. Quando o país elabora um novo pacto com outros países do Sul, isto é, com a Argentina, Uruguai, Paraguai, Bolívia e o Chile, objeto que será tema de outra palestra minha em outro lugar desta cidade, num outro momento, isso vai ter uma repercussão certa sobre o espaço brasileiro. Mas, e aí, os senhores? Os senhores, finalmente, são planejadores de quê? De 
coisa nenhuma. Enquanto que nós, os geógrafos, podemos pelo menos, se nos dão recursos, ou ainda, se recursos são bastante inteligentes e capazes, que é o meu caso, tentar a interpretação desses fenômenos em função de fatores que a gente pode conhecer, que há o contato com o mundo externo, porque a informação dentro do país nas universidades é muito limitada; as bibliotecas são o que elas são, todo mundo sabe disso, e o acesso a ela é o que ela é, sem contar que as pessoas não gostam muito de ler. Então, eu penso que o progresso dentro da geografia pode ser mais rápido e pode impulsionar o progresso do planejamento, na medida em que a geografia deixe de ser o que ela é, e passe a ser uma espaciologia, como propusemos, ao mesmo tempo, eu próprio e Henri Lefebvre, isso é, a grande disciplina do futuro da humanidade. Acho que nós poderemos juntos fazer isso. Mas, me parece. Mas, por enquanto, o planejamento não é planejamento. É uma espécie de brinquedo que põe na mão de certo número de pessoas, que não tem eficácia, porque os instrumentos que, realmente, tem ação sobre espaço não estão comandados pelo ministério, nem do planejamento nem da urbanização. São o resultado de ações muito mais dinâmicas sobre a reorganização do território que a dos ministérios territoriais. De tarde então falaremos na economia política da cidade.

Coordenador Aldo Paviani:

Respeitando o cansaço do professor Milton Santos e o nosso para acompanhar os seus argutos raciocínios, eu consulto a platéia se poderemos estar aqui, todos, pelas quatorze e trinta, para começar a sessão da tarde. Aos debatedores, sim? Como não há manifestação contrária, estaremos aqui com os agradecimentos pela presença, não só do ilustre conferencista, como dos senhores.

(...) Intervalo de almoço

Coordenador Aldo Paviani

Retornando ao que se falou de manhã, desejo apresentar ao professor Milton Santos, o reconhecimento de uma universidade importante pelo seu trabalho em prol de um mundo melhor. Nós receberemos perguntas por escrito ou no microfone para que todos possam ouvir. Professor Ricardo Farret - tem alguma coisa a colocar?

\section{Professor Milton Santos:}

O que eu comecei a tentar responder ao colega Farret esta manhã é como viver a cidade ideal, nessa mesma ótica globalizante que a gente quis oferecer. Quem sabe a gente não começa com algumas considerações quem sabe, filosóficas. A totalidade é para o homem, o mundo em que nós vivemos. A totalidade se organiza em diferentes níveis. $\mathrm{O}$ cristal, por exemplo, é uma forma de organização da totalidade diferente, digamos assim, de um 'glaci' ou de peneplanície, ainda se usa essa expressão? Onde um conjunto em que apareça um determinado tipo de clima e paleoclima associado a certo tipo de relevo, de solo, de vegetação. Então, temos diversos níveis de organização da totalidade, 
que, às vezes, dão como resultado totalidades menores, isto é, totalidades, conjuntos que são também totalidades dentro da totalidade maior. A mim parece que a cidade o organismo urbano é uma dessas totalidades menores, no interior da totalidade maior que é o mundo, intermediada ela em relação ao mundo por uma formação social especifica que é o conjunto da nação e do estado em um país dado. Essa totalidade, a cidade tem uma especificidade dentro de um país pelo fato de que é, entre os subespaços que um país é constituído, um único subespaço capaz de manter relações com os demais. Digamos que num país haja um subespaço puramente agrícola, se acaso isso existisse, que haja um subespaço mineiro (de mineração) que haja um subespaço industrial, mas esse espaço não dispõe de um aparato capaz de permitir que a vida e relações, e as relações entre os espaço se façam. A cidade é este aparato. Constitui esse instrumento, esse subespaço que é capaz de manter, se não de criar, sobretudo manter, relações entre os demais subespaços. Essa é uma das suas especificidades. Essa especificidade da cidade é que fez dela durante muito tempo um lugar do terciário. Ela ainda é hoje lugar do terciário porque o terciário está ligado ao tipo de relações.

Somente que a industrialização moderna, necessitando de um conjunto de infraestruturas, que a gente pode chamar de capital auxiliar, isto é, aquele capital que permite ao capital especulativo de oferecer rendimento ao seu proprietário. Isso faz com que a cidade se torne cada vez mais o lugar da produção. A rede urbana é o esqueleto produtivo de um país. As cidades constituem aquele lugar onde se realiza a maior parte da produção bruta, do volume da produção nacional e, ao mesmo tempo, onde o terciário alcança igualmente um volume maior, tanto do ponto de vista das atividades ali desempenhadas, como do produto que ele gera. Isso está ligado, em grande parte, à fase atual da história que vivemos. Não esquecer que cada pedaço de espaço que se cria incorpora, hoje, técnica, isto é, tecnologia e ciência. Os novos espaços são, tanto no mundo agrário quanto no mundo urbano, espaços que são de um lado, espaço altamente tecnicizados e espaços altamente cientifizados. Isto é, há uma participação cada vez mais crescente, um input cada vez maior de tecnologia e de ciência na elaboração dos espaços. É isso que dá ao espaço uma característica específica no mundo de hoje. Por isso que ele tem esse comando particular na vida social e econômica, porque os objetos nele colocados vêm carregados desse conteúdo cientifico e técnico, que são um dado essencial da capacidade de produção. Mas, a cidade não é utilizada da mesma forma por todos. A cidade aí está - esta como qualquer outra - ela parece como sendo a cidade dos cidadãos. Ela parece como sendo a cidade das atividades, das instituições, ela o é diferentemente para diferentes classes de homens, diferentes classes de instituições e diferentes classes de atividades. Aí se coloca a questão do poder. Há atividades que usam mais ou menos a cidade porque tem mais ou menos poder. Homens que usam mais ou menos a cidade porque têm mais ou menos poder e instituições que dispõem de mais ou menos poder para usar acidade. E mais: há homens que têm mais ou menos poder para mudar a cidade. Há instituições que têm mais ou menos poder para mudar a cidade e há firmas que têm mais ou menos poder para mudar a cidade. A evolução 
urbana não é um dado que se possa atribuir ao acaso. Pode parecer como resultado do acaso, mas não é; ela obedece a leis, que ainda que não possamos formular à primeira vista, nem por isso deixam de ser leis e nesse caso, e é por isso mesmo que, me parece, que a compreensão da cidade passa pela economia política. Uma cidade em que as classes que detém as possibilidades de acesso ao poder podem utilizá-lo pelo fato de terem recursos no sentido de fazer indústrias. Uma cidade onde as classes que têm acesso ao poder não têm a capacidade de criação de indústrias. Vamos tomar os exemplos de São Paulo e do Rio de Janeiro. Então, nós vemos que os homens que têm o poder no Rio de Janeiro, na sua maior parte, não têm o poder da criação de grandes indústrias, enquanto que, em São Paulo, os homens que têm o poder financeiro, econômico, são industriais. Isso tem uma implicação na forma como a cidade se organiza, evolui e mesmo na própria organização do espaço exterior da cidade. Quem sabe se a incapacidade do Rio de Janeiro de se autoabastecer em alimentos não está diretamente ligado ao fato de que a especulação é um negócio dos especuladores e políticos cariocas. Todo mundo sabe que o Rio um dia pode se abastecer em alimentos, todo mundo sabe que hoje o Rio de Janeiro é obrigado a comprar uma boa parte dos alimentos que consome da área de São Paulo. Ora, a cidade, ou as cidades nas quais os homens que detém o poder político não dispõem de outro instrumento de trabalho capitalista que não seja a especulação, é uma cidade ingovernável, porque o poder está em suas mãos. O poder financeiro só pode se realizar através a própria cidade. O espaço urbano é que é o negócio do político e nesse caso a cidade se torna ingovernável.

Eu tive a oportunidade de dizer isso a um dos prefeitos de uma das cidades brasileiras que teve a gentileza de me convidar quando tomou posse, disse-lhe que ele não poderia governar sua cidade exatamente porque a cidade era o negócio dos políticos que dirigiam a política local. É o caso do Rio de Janeiro. É o caso também de muitas cidades brasileiras. Evidente que eu estou tomando um aspecto da questão. Eles são muitos, muitos e variados, mas isso já nos dá uma pista e nos mostra como, se a gente não tem um conhecimento de ciência política, se não tem como tratar as informações que por acaso nos vêm às mãos, sobre o setor policial; se a gente não sabe ler os jornais, ou inclusive repertórios como esse, da visão quem é quem, etc. A gente também é incapaz de compreender realmente a vida urbana, e se torna incapaz de efetuar, digamos assim, o estudo que seja útil. Não digo utilizado. Os estudos úteis não são necessariamente utilizados, ao contrário, ou são utilizados ao contrário. Mas, o dever nosso é de buscar fazer estudos úteis, isto é, em que agente busque atingir a realidade das coisas tal como elas se passam. Por isso que disse que a geografia urbana tornou incapaz de se exercer. Nós insistimos em manter essa disciplina com esse nome e queria talvez, como dizer a Farret, uma coisa que o nosso mestre Descartes, meu mestre e o geógrafo mais importante na formação dos geógrafos da América Latina, o professor Tricart professor também de Maria Novais, de dezenas de geógrafos por esse país afora escreveu o mais importante livro de geografia urbana jamais escrito. Ele que hoje é apenas geomorfólogo escreveu, nos anos 50, a edição não tem data certa, mas imagino que é de 1954, um livro, que não chega a ser livro porque é um cahier, lá do CDI 
(Centre de Documentacion Universitaire), da Universidade Sorbonne, que se chama... como chama? (VER título) Que é sobre a organização interna da cidade, exatamente onde ele, como marxista que é e que foi e que continua sendo, busca aplicar o método marxista à geografia urbana como aplica à geomorfologia, por mais incrível que pareça e nos oferece esse esplêndido livro que é muito difícil de encontrar, porque dele foram tirados (edição limitada) mil ou dois mil exemplares. Não foi tirada segunda edição, mas, que se encontrar editor, tentarei publicá-lo, porque durante alguns meses em que tive tempo no ano de 1964, eu operei a tradução desse livro. Estou buscando editor. Nessa ocasião, esse livro foi completado com exemplos brasileiros elaborados no nosso finado laboratório por diversos colégios, mas sobre tudo por Ana Carvalho e por mim mesmo. Esses exemplos estando hoje envelhecidos, de modo que a aplicação se faria sem esses documentos.

Nesse livro o que aparece é o que hoje também vemos, isto é, cada coisa tem um lugar próprio no espaço. Nada se dá no espaço sem que seja o resultado de uma lógica. As coisas estão aqui ou ali como resultado de uma lógica, que é a lógica do global, que é a lógica dada pela luta das instituições, das empresas e dos homens para ocupar tal ou qual lugar dentro da cidade. Isso é um dado permanente da vida urbana. Eu me recordo de haver escrito, me desculpem essa reminiscência, um artigo de que a polícia da Bahia deliberou tirar as prostitutas daquela área que fica em torno das igrejas e que a elas pertence. Falo dos prédios não das prostitutas e escrevi um artigo de uma página inteira cujo titulo era "Elas voltarão". O que aconteceu, porque era o lugar próprio para o dito comércio. As cidades têm lugares próprios para tal qual atividade, esses lugares mudam, às vezes, essas localizações mudam espontaneamente. Não podemos apressar essas mudanças, mas há sempre lugares próprios para cada coisa dentro da cidade e em um dado momento. Somente algumas atividades têm força para criar novos quadros de realização das atividades. Os quadros antigos, os casos pré-existentes abrigam atividades menos poderosas, menos dinâmicas, segundo leis que são de um lado gerais a todas as cidades, mas que são específicas de cada cidade. Esse é um tema que me parece bastante interessante para analisar.

Outro tema interessante analisar é a questão da relação entre a cidade como espaço construído e a realização do valor. Sabemos que há uma relação entre forma e conteúdo, explorada desde os filósofos antigos, teve em Hegel o seu grande formulador, em Marx, um grande seguidor. Fato que continua sendo explorado por homens como Sartre e Marcuse, mas também por aqueles filósofos alemães da Escola de Frankfurt. Essa relação entre forma e conteúdo é fundamental para a compreensão de qualquer que seja o dado geográfico, fato geográfico, é um elemento que pertence à compreensão da filosofia geral, mas que é um caminho extremamente frutuoso para a compreensão de como a cidade funciona. 
O que é uma forma? Uma forma (não vou dar uma definição, as definições me fazem medo porque elas nos aprisionam, retificam o nosso pensamento). Mas, vamos tentar conversar sobre isso. Uma forma é algo criado num momento ' $\mathrm{x}$ ' para abrigar um conteúdo 'yx'. Isso é a forma nova. A forma nova nasce com a técnica do momento em que o fenômeno novo necessitou a sua criação. Os fenômenos envelhecem e as formas ficam. Esse é que é o grande problema: do espaço como um todo e da cidade em particular. Evidente que cidades como São Paulo, que puderam num certo período jogar abaixo prédios, inclusive de certa importância, para construir outros. Isso só foi feito em alguns lugares, mas ao mesmo tempo alguns prédios antigos permaneciam. Quer dizer que há essa presença do que seria aparentemente o presente e o passado. O passado animado pelo presente que é dado pelo conteúdo que é sempre o presente. Ora, quando os usos da cidade se tornam extremamente modificados, renovados e as formas não se renovam, o que acontece é que, a cidade como um meio de produção, é um obstáculo à realização da mais valia, do lucro. Há uma tendência a queda do rendimento médio das atividades. Então, é necessário renovar a cidade seja por fora seja por dentro na medida em que essa renovação vai possibilitar ao capital reencontrar aquela ambiência, aquele clima, isto é, aquele espaço construído. (Mudança de fita, agora a de numero 4) [Talvez, Ignez, seja melhor cortar a meia-frase abaixo, entre colchetes]

[(...) ou com trabalho mais que com o capital.] O caso de São Paulo é típico. Quando se fala, por exemplo, de economia de aglomeração, economia de escala, inviabilidade da cidade: São Paulo é um belíssimo exemplo de inviabilizações, seguidas muitas vezes de reviabilizações. Cada vez que São Paulo se inviabiliza, o poder público, isto é, os governos, utilizando dinheiro público, reviabilizam a cidade de São Paulo de maneira que os capitais novos e, a cada momento, esses capitais novos não são os mesmos, possam utilizar a cidade de maneira "profitável”, isto é, de maneira que lhes dê o maior lucro, até o momento em que o processo de reviabilização se torna, quem sabe, impossível e se é obrigado a que? Obrigado a propor simplesmente a mudança da capital do estado. O que é a mudança da capital de São Paulo senão o resultado da impossibilidade atual de reviabilizar a cidade para o uso pelos capitais novos. Os grandíssimos capitais nacionais, mas, sobretudo, internacionais que fazem da cidade o seu meio; meio do qual podem extrair a mais valia. Por isso, é que não me agradou o debate estabelecido em torno da capital de São Paulo, tanto do lado do que se chama a situação, como do lado que se chama oposição. Tanto do lado que se chama direita representada, dizem, pelo governador do estado de São Paulo, não sei, não analisei a personalidade do cidadão e pelas chamadas esquerdas, que jamais discutiram o problema de uma forma que me pareça uma forma científica.

A cidade de São Paulo tinha que ser mudada. A capital do estado de São Paulo e o ministro de estado da urbanização, que levou um ano resistindo, cedeu hoje de manhã, parece. Considerando a absoluta necessidade de se fazer essa cidade, por quê? Por que fazer essa cidade? Se eu pudesse não falar no microfone, porque eu queria ir ao quadro negro mostrar o que vai acontecer. A cidade de São Paulo para se reviabilizar tinha que criar novas auréolas, cada vez maiores. Aqui está a Avenida Paulista. Aqui está a 
Avenida Faria Lima. Aqui estão as avenidas formadas pelas marginais, etc. Só que a cada reviabilização da cidade de São Paulo, os espaços novos não eram ocupados por uma porcentagem de população correspondente. Estava claro que os recursos públicos eram utilizados para viabilizar as instalações das indústrias, sobretudo, uma fase em que, como todos nós sabemos, a circulação tomou a importância que tem e, por conseguinte, era necessário que a produção pudesse rapidamente circular de um lugar a outro e sair de São Paulo. Se demorar muito tempo, a volta do capital à indústria demora muito tempo também. Isso seria contrário às leis do capitalismo na fase atual da história internacional.

Então, não havia outra solução, senão a de criar uma completamente nova cidade. Por quê? Para que a cidade seja constituída exclusivamente de novas formas. De formas cientifica e tecnicamente elaboradas para receber as atividades que prometem nela se instalar e que terão por consequência um resultado excelente para elas, enquanto nós pagamos a construção da cidade. Tem mais: essa nova cidade foi concebida, não me importa o aspecto moral da coisa; isso não tem a menor importância. Tem importância menor na história dos povos que o senhor fulano de tal queira vender os seus terrenos, tem certa importância mais não tem uma tão grande importância. Então, aqui está o lugar onde vai ser construída a cidade, que será dotada, certamente, de vias bastante rápidas que levarão às cidades médias e às distantes. Ora, esses terrenos aqui terão uso privilegiado, de tal maneira que os pobres serão atraídos, como sempre são atraídos pelo capital - onde está o capital, está o pobre. É uma aliança indispensável. Os pobres se aglomerarão nessa cidade, de maneira que as pessoas que estão aqui fiquem tranquilas, eles virão trabalhar. Montaram seu lugar de trabalho através de vias bastante expressivas e haverá, ao mesmo tempo, apesar da aglomeração dos operários no lugar onde está hoje, o que numa fase de crise é um “maná”, na medida em que eles vão perder uma parte da sua agressividade pela sua dissociação geográfica. Quer dizer, isso é geopolítica interna. Há uma área dada do país, essa cidade aparece com uma necessidade do capitalismo mundial com a necessidade do capitalismo nacional, paulista e paulistano. Era assim que tinha que ser feito. E nós, que fizemos? Começamos a gritar "somos contra a cidade", misturando dois lados, em vez de estudarmos o que tinha que fazer da cidade que tinha que ser feita. (Ele adora o som "o que é justo é justo”, comenta Milton - não lembro a que se referia). Então, é isso que eu penso que é importante, digamos assim, tentar fazer dentro da nossa disciplina geográfica.

O discurso geográfico, às vezes, se deixa embalar pela fraseologia, pela diatribe, pelo gosto das palavras. Quando a gente podia utilizar a nossa força de combate e, quem sabe, a nossa inteligência, numa tentativa de análise do que está se passando, do que vai se passar, e em vez de perder tempo apenas com o xingamento, a gente usasse o tempo xingando também porque a denúncia tem que ser feita e faz parte do jogo político. Mas, trabalhando, igualmente, na medida em que a decisão afinal anunciada, porque já estava 
tomada há muito tempo. Ela foi anunciada no exato momento político de ser anunciada, mas ela já estava tomada. Nos pega de surpresa.

Então, é assim que eu vejo as novas formas de análise, digamos, das cidades, que poderia também a levar a compreender a questão, por exemplo, do Projeto Rio. O que é o Projeto Rio? O projeto, chamado de renovação não sei de que, daquela área que está perto da Ilha do Fundão (Milton se referia à "urbanização da favela da Maré”). Os pobres que estavam querendo entrar na universidade. Quer dizer, não sei se vocês conhecem o Rio de Janeiro. Então havia aquele avanço das favelas para a universidade, tanto que se fará. O problema é que há uma relação entre espaço e cultura. O grande espaço, segunda natureza, lendo a natureza segundo Marx, a gente se refere à natureza, as coisa, os objeto, a segunda natureza, como escrevi aí nesse livrinho cor de rosa (ele agora é marrom, na segunda edição), a segunda natureza é o que as obras dos homens modificam a natureza. Mas, a segunda a natureza também é cultura, a cultura de massa, que se opõe à cultura popular. Nós sabemos que há uma cultura de massa, isto é, aquela que nos é imposta pelos instrumentos de comunicação de massa. O bom senso que nos é aconselhado por esses perigosos instrumentos, que são as televisões, os jornais, as universidades, etc. Essa cultura de massa, que se opõe à cultura popular. Eu diria, entre parêntese, que o grande bem feito desses quinze anos que o Brasil está terminando de viver foi o fato da criação de tantos pobres. Isso salvou o país. Imagina se fossemos nós que tivéssemos, se todos eles tivessem chegado à universidade - que desgraça - que ficassem como nós cosmopolitas voltados para o estrangeiro, como somos.

A cultura nacional não somos nós os guardiões dela, são o povo. Então, o fato de que os pobres tivessem aumentado e a sua pobreza tivesse aumentado, para salvar o país. Só que a salvação do país depende muito de que haja uma relação entre a coisa construída pelo pobre e a cultura construída pelo pobre. O Projeto Rio me parece típico de uma operação pela qual uma cultura popular enraizada no habitat popular, por conseguinte capaz de gerar uma consciência popular, tem que ser destruída. Temos que levar os pobres para um outro quadro geográfico, arquitetônico, urbanístico, onde essa cultura popular se desmembre como se desmembrarão as solidariedades criadas pela vida em comum, retardando a tomada de consciência da sua própria condição, porque a tomada de consciência da condição do homem passa pelo seu lugar, no espaço. Então, é outra proposta que eu estou fazendo, no sentido de uma renovação na forma de compreensão da cidade e que leva em conta, como estão vendo, a questão dos valores, que parece preocupar o meu querido Saint Clair, e a professora que, abnegadamente, eu me dirijo, abnegada por ela não por você, porque você é uma pessoa que, me parece, me dirigir é um privilégio. Então, essa questão dos valores está muito intimamente ligada à noção de forma urbana. Está muito intimamente ligada à questão da organização do espaço e a velha geografia urbana não nos dá nenhuma maneira de enfrentar esse tipo de problema, que é um problema real. A descrição pura e simples de onde está o comércio, de onde está a indústria, é muito pouco, era um começo, mas é muito pouco, ela não nos permite ver a totalidade dos problemas e não nos permite brigar por uma solução que seja mais justa, ou que nós entendamos mais justa. 
Eu não sei se com esses fragmentos de coisas que ainda não escrevi porque estou amadurecendo. Penso muito devagar. Estou amadurecendo, antes de lançar algo mais, digamos assim, mais provisoriamente definitivo. Imagino que é nessa direção que deveríamos andar. Não sei se Farret vai ainda me fazer mais provocações, gostaria que ele fizesse outras, mas não sei também se consegui responder, enfim.

Pergunta escrita:

"Gostaria que explicitasse um pouco mais profundamente o conceito formulado de cidade como meio de produção.”

Professor Milton Santos responde:

Bom, o que é um meio de produção? Um meio de produção é um instrumento de produção, um conjunto de instrumentos de produção e mais o environment (sei que todo mundo aqui fala inglês) o environement, como nós falávamos, no passado, na nossa geração, o entorno, que possibilita o uso desse instrumento de produção. Veja Manhattan. Qual a produção de Manhattan? É matéria cinzenta, sobretudo. Como certas áreas de São Paulo produzem matéria cinzenta. Onde a concentração, por exemplo, de universidades, em Manhattan, a gente tem uma quantidade de universidades de alta qualidade, de institutos de pesquisa de alta qualidade, de organização de investigação, de programação, de planejamento, (o diabo né), os bancos com seus institutos de pesquisa e de fusão do que encontram e querem divulgar. Tudo isso constitui um meio da produção terciária, que escolhe ou privilegia uma parte da cidade. Mas ela é também um meio de produção do chamado secundário, da atividade industrial. É nesse sentido que eu falei da cidade como meio de produção. Isto é instrumento de produção dentre os quais o solo urbano, não quis dizer isso para chocar as pessoas porque o assunto 'solo urbano' parece um pouco amesquinhado. O solo urbano, hoje, o valor dele não vem dele, mas vem de tudo que lhe seja agregado pelo poder público, ou das vias que o contornam e fazem com que esse pedaço de solo seja mais ou menos viável para este ou aquele tipo de capital, quantitativamente e qualitativamente. Então é nesse sentido que falo da cidade como meio de produção.

Pergunta do estudante Paulo Lopes:

Paulo Lopes me pergunta: “A nova capital do estado de São Paulo não poderá provocar uma inchação na população periférica e saturação do mercado de trabalho, provocando um crescimento horizontal, acarretando problemas até mais sérios do que os que existem agora na atual capital?”

Bom, o que a pessoa pergunta é o seguinte: se se desloca a capital de São Paulo para outro lugar, Brotas, por exemplo. São Paulo vai continuar crescendo. Será que São Paulo, cidade de São Paulo SP, como dizem os paulistas, vai atrair ainda mais população pobre que saturará o mercado de trabalho e vai provocar um crescimento 
horizontal. Mas advirto que sim, toda grande cidade tem um poder de atração dos pobres maior do que as cidades menores. Mas a questão da capital nova de São Paulo não está colocada do ponto de vista dos pobres, está colocada do ponto de vista do capital. Ela está sendo criada para servir o capital. Os pobres são um obstáculo, às vezes, quando são demasiadamente numerosos e tem capacidade de organização. Mas, as vias públicas são muito mais utilizadas pelo econômico do que pelo social. Quem que utiliza as grandes vias modernas de uma cidade, de aglomeração, como é a aglomeração paulistana? Não são os indivíduos, são as firmas, de modo que haverá problemas sérios mais para os pobres. Mas quem está se preocupando com os pobres? Ainda não chegou a vez de uma preocupação séria e real com os pobres. O que está em jogo agora é que a economia continue o seu crescimento porque, quando houver preocupação com os pobres, a própria estrutura produtiva terá que mudar. Nesse caso, o uso das formas geográficas que hoje abrigam tal ou qual atividade será outro. A dinâmica do emprego será outra, e em vez de oito professores no Instituto de Geografia de Brasília é melhor dezesseis. Em vez de haver mais médicos do que assistentes hospitalares - o Brasil é o único país que isso acontece - haverá mais assistentes hospitalares se outra fosse a equação produtiva e conceptiva. Haverá mais professores primários, haverá mais assistentes sociais.

Então, a questão do emprego ela passa pela questão da estrutura produtiva. Então, a cidade estaria muito mais apta a aceitar, digamos, as atividades sociais que não exigem tanto a modificação do quadro urbano. Prova é que essas faculdades que se criam em qualquer esquina, utilizam exatamente os velhos quadros urbanos. Onde é que estão as faculdades particulares de São Paulo, Salvador, Rio de Janeiro, do Recife, senão nas velhas casas, onde se não fossemos megalômanos poderíamos também criar hotéis restaurantes, etc. e criar condições para criar curativos menores, uma medicina preventiva etc. Quer dizer, que as atividades sociais não são tão exigentes numa mudança de quadro urbano e geográfico, que leve as despesas que são arcadas pela população em geral. Isto é, um novo pacto social permitiria enfrentar esses problemas com muito menos dinheiro, com muito menos gastos. Mas, só uma visão global é que permite chegar a essa conclusão, porque do contrário a gente fica repetindo que as coisas custam mais caro, que distribuir mais educação é mais caro, que distribuir mais saúde é impossível, porque faltam recursos Não faltam recursos para possibilitar ao capital o seu exercício.

Outra pergunta é: “As zonas periféricas urbanas têm sofrido uma expansão territorial acentuada nos últimos anos. Diante disso, pode se afirmar que as zonas perifericamente urbanas não existiam politicamente há 50 anos.”

O fenômeno da suburbanização é um fenômeno que ocorreu com atraso no nosso país, por razões que não vou detalhar agora. Ocorreu no Rio de Janeiro antes que nos outros estados, inteiramente ligado ao fato que o Rio de Janeiro foi a primeira grande cidade moderna do Brasil. A expansão urbana, digamos, formando zonas periféricas é um dado digamos relativamente recente no Brasil devido a essas causas que todo mundo 
conhece. Não vou detalhar. Então, quem sabe, isso responde à pergunta se ela existiu antes de 50 anos. A pergunta que deveria ser feita era a seguinte: elas existem politicamente, hoje. Aí, vem a resposta que está ligada também à economia política das cidades. Como estão distribuídos, como estão divididas as regiões metropolitanas do ponto de vista da administração e da política? Pense nisso.

Eu não vou trabalhar nesse assunto hoje, não. Vou deixar vocês pensarem nisso e, no próximo convite, porque eu serei, certamente, convidado a voltar e dar uma conferência aqui, a gente então vai discutir.

Como são organizadas politicamente as zonas metropolitanas? Além daquilo que eu falei “um grande município no meio e os pequenininhos em torno”...

Outra pergunta: "Quais as influências de um processo tecnológico importado na organização do espaço? O espaço, recebendo essa influência não seria um espaço com pouca ou nenhuma identidade própria? Seria apenas um espaço derivado?”

Muito obrigado. Quem escreveu isso aí mostra que me leu. Isso aumenta a minha vaidade cotidiana. Mas, é bom porque me tira do cotidiano também. Então, realmente, um espaço derivado é um espaço desculturizante. O que é terrível: com as técnicas modernas, é que elas se instalam em qualquer parte, sem respeito pelo local onde elas se instalam. Quer dizer que, me foi contado em uma palestra que dei em São Paulo, o episódio daquela senhora a mãe ou avó de um dos presentes, que já não saía mais na rua pelo fato de que já não reconhecia a sua cidade. Não sabia mais do que se tratava. Quer dizer que, no nosso tempo de vida, o espaço que nos rodeia muda várias vezes, e termina por nos transformar, se não tomarmos cuidado, em pessoas alienadas; que é o grande objetivo da reconstrução do espaço no nosso tempo, e, também, ajudar na criação do homem alienado, na medida em que a gente é inclusive incapaz de tomar conhecimento do que a cidade é como um todo e que a gente, para usar a expressão daquele sociólogo urbano Raymond Ledrut, conhece aquele lugar do seu trabalho, o lugar onde vive, o lugar onde se distrai, e o caminho entre esses lugares e mais nada. Então, me parece que realmente as técnicas modernas têm um papel extremamente importante. Mas, a técnica, por si só, não é o bastante pra explicar coisa nenhuma. A gente tem que ligar a técnica ao que está por trás dela, àquilo que a técnica serve. As técnicas atuais podem ser utilizadas de outra forma e um dia serão utilizadas de outra forma. Aí está, de novo, o problema da forma, do conteúdo, que deveria ser objeto de uma preocupação muito grande da nossa parte e que afinal nos dá esperança.

Eu quero dizer pra vocês que a própria idéia que expus esta manhã aqui da separação com categoria (...) (perda por mudança de lado da fita)

(...) podem ser utilizadas de maneira diferente se as estruturas sociopolíticas mudam e trabalhar esta idéia que é prenhe de esperança, somente é possível através de novas 
categorias de trabalho geográfico inclusive essa que propus pela amanhã: há distinção entre a paisagem e o espaço. Isso me veio com uma necessidade política, de encontrar uma saída, dentro do trabalho científico, uma visão do futuro.

Outra pergunta: "Como nos países em que você trabalha, ou trabalhou, veja Venezuela, a Guiné Bissau, etc., os resultados dessas pesquisas são aproveitados pelos governos para a solução dos reais problemas das populações?”

Os governos, ou estados têm o dever de dar trabalho a todo mundo. O trabalho é direito de todos os cidadãos. Está nas constituições de todos os países. Trabalhar na administração pública não é trabalhar para o governo. É, quanto muito, trabalhar para o Estado. A universidade é diferente, porque a universidade é o lugar da contestação, por excelência. E os governos têm o dever de dar dinheiro para os professores pensarem e escreverem contra ele. Ainda que se escreva para ele, mas que somente para ele, porque o Estado, a nação, é formado de instituições múltiplas. Os partidos quando existem, os sindicatos quando existem. E o que se escreve é utilizado, em parte, hoje, pelos governos e, amanhã, quem sabe, por outras instituições e, hoje, também, o seu discurso. No caso da Venezuela, onde a minha presença se tornou frequente exatamente pelo fato de haver dela sido expulso pelas Nações Unidas, porque não fiz o que era me foi solicitado, que era um desserviço à nação. É isso que faz com que os venezuelanos me sempre convidam para voltar lá.

O pouco que tenho contribuído é muito pouco porque ninguém contribui muito no país dos outros. No país dos outros, a gente só contribui pouco e devemos sempre ter o cuidado de contribuir pouco, no país dos outros, porque o intelectual, que não é cidadão, a sua contribuição é sempre limitada, ainda que não haja lei de migrantes. Então, o que acontece é que essa contribuição deve ser uma migalha, no conjunto de coisas que se elaboram no país. No caso da Guiné Bissau, minha contribuição, por enquanto, foi nenhuma, ao contrário, apenas fui lá aprender. Fui pago pelo país, que é um país pobre, para aprender. Estive lá sendo pago para estudar através do que já tinha sido feito por outros. É evidente que esse estudo vai me possibilitar que chegue a algumas conclusões. Mas não as tenho, hoje, para oferecer.

De todo modo, há que pensar em que a Venezuela e Guiné Bissau têm uma diferença muito grande. Em Guiné Bissau, cada indivíduo, cada cidadão, está preocupado com a construção da sua nação. Os pobres são dignos, os intelectuais buscam ser puros e politicamente orientados. A Venezuela é um país já corrompido pela modernização capitalista, onde os homens querem ser coisas, onde a preocupação consigo mesmo é muitas vezes mais importante; de onde se tem, por isso mesmo, que lutar para oferecer ideias. Então, cada país é um contexto diferente. O que não quer dizer que, na Venezuela, haja grande número, um crescente número de pessoas que se interessam pelo seu país, pelo futuro do seu país, um futuro diferente do que ele é hoje. Eu acho que assim que eu posso responder essa pergunta.

Pergunta: 
"Como deve ser a atitude dos povos pertencentes aos espaços desorganizados do Terceiro Mundo para conseguir uma nova ordem mais justa e uma organização espacial consequente?”

Primeiro: não há nenhum espaço que seja desorganizado. Isto não existe. Os nossos maiores geógrafos que nos ensinaram e que nós lemos com agrado ainda, falam, às vezes, de rede urbana desorganizada, inorganizada etc. Isto não existe. Não há desordem no mundo. Não haveria mundo se não houvesse ordem. O mundo e ordem são sinônimos. Todas as coisas são resultado de uma ordem. Isto não existe: não há espaço desorganizado. Há formas diferentes de organização que é preciso penetrar. Creio mesmo que essa expressão que a gente vê repetida na boca de tantos dos nossos colegas franceses, e de outras nacionalidades, constitui um instrumento de nosso desnorteamento. Desnorteamento que é grande porque, às vezes, a gente quer adotar, adaptar, modelos que não têm nada a ver com os nossos. Então, a gente busca encontrar no nosso país o espaço que existe lá, e quando não encontra a gente diz que não está certo, que a gente não está certo; que aquilo não é bom, etc. Escreve não é, mesmo quando o texto inteiro leva a outra conclusão.

Então, visto o drama de muitos colegas que fazem teses ou escritos, que desenvolvem um raciocínio inteligente e, na hora de concluir, não podem fazê-lo, ou fazem mal, exatamente porque estão prisioneiros da teoria que lhes foi fornecida de fora. Felizmente, que estamos no Brasil, hoje, começando a elaborar uma filosofia e uma teoria própria do espaço, onde, naturalmente, as pessoas mesmo que não querendo citar, porque é muito mais interessante, do ponto de vista da briga acadêmica, citar um estrangeiro, não é? E reconheço que as pessoas têm que se curvar às contingências da elaboração de sua própria carreira. Mas, estão se forjando novos instrumentos de colaboração, de elaboração. Esses instrumentos não são forjados apenas por geógrafos do Terceiro Mundo, mas também por geógrafo do Primeiro Mundo, homens de boa vontade. Imagino que vocês têm, entre vocês, um colega que não é brasileiro, mas que me parece ser um homem de boa vontade. Há muitos desses homens de boa vontade em outros países como Yves La Coste, Bernard Kaiser, como Michel Rochefort, Richard Pink, David Harvey, como, enfim, como uma dezena deles, como Manuel Castells que é meio geógrafo, etc. etc. etc. como McGee, que estão colaborando na elaboração de uma forma melhor de compreensão do nosso espaço. Só tem que uma coisa: é que todos esses senhores fazem no nosso país o que nós podemos fazer. O que nós precisamos que eles façam é de estudar no país deles, o que nos faz subdesenvolvidos. Essa coisa de virem para cá, esses terceiro-mundistas europeus, americanos, canadenses e outros, para estudar aqui o nosso subdesenvolvimento, não nos interessa. O que nos interessa é que eles, exceto os que são realmente geniais, mas as pessoas geniais na geografia não são muito numerosas, não por culpa própria, mas por culpa da estrutura do ensino que é limitativa. Que eles estudem nos países deles o que nos faz subdesenvolvidos, porque do contrário o que eles estão fazendo ainda é aquele discurso inócuo, que nos parece um 
discurso progressista e, na verdade, não é. O que nos queremos saber é o que alguns fazendo na Holanda, por exemplo, estudando como funcionam certas corporações holandesas na sua ação no terceiro mundo.

O que estão fazendo alguns geógrafos na Bélgica, estudando como funcionam certas corporações belgas nas suas relações com o Terceiro Mundo. O que estão fazendo alguns colegas na Dinamarca estudando o que fazem certas corporações, dentro do país deles, e o estado, dentro dos países deles, em relação ao Terceiro Mundo. Não é fazerem pagar férias nos nossos países para repetir de uma forma diferente aquilo que nós já escrevemos ou que nós podemos fazer por nós mesmos. Não desejo que não nos venham visitar, ao contrário, é sempre grato encontrar um colega, sobretudo um amigo, porque o que estou dizendo, estou também me referindo aos meus amigos. Mas, temos que opor um basta e dizer-lhes isto. O que nos falta exatamente para um melhor trabalho na compreensão do espaço o Terceiro Mundo é que nossos coleguinhas, esquerdizantes ou terceiro-mundistas ou brasilianistas façam nos países porque nós não temos acesso a essas informações. Então o nosso trabalho é truncado a gente vê um lado da questão e não vê o outro.

Espero que cada colega estrangeiro que venha aqui dar conferência, essa pergunta lhe seja feita. Por favor, tomem nota e não se esqueçam de lhe fazer essa pergunta. De maneira polida, correta, como deve ser na universidade, mas tem que ser feito, porque isso nos é fundamental para compreender o nosso estado de subdesenvolvimento. Ora, os povos que pertencem aos países subdesenvolvidos não se conhecem, simplesmente. Outro dia eu fiz uma plenária com uma mocinha que veio me ver e ia para a Alemanha estudar. Tomei um ar severo e perguntei, porque você não vai estudar na Tanzânia ou no Quênia - para ver a cara que ela fazia! Porque, evidentemente, os africanos são inteiramente brutos, embrutecidos, burríssimos, não é? E o que tem para fazer lá, não tem nada o que aprender com animal daqueles a gente só pode aprender na Alemanha, na França, no Canadá, na Suécia.

A gente jamais convidou um colega africano, exceto se ele é um instrumento dos países do norte para trazermos sua voz. Não, não nos interessa. Ainda no último congresso de geografia, organizado pelo grupo ao qual faço mais ou menos parte, a minha insistência foi muito grande para que se trouxessem colegas dos países subdesenvolvidos, que, afinal, vieram e disseram muito pouca coisa interessante. Então, os países subdesenvolvidos não se conhecem, não se querem conhecer. A única associação de geógrafos latino-americanos, que, parece, vai se reunir aqui neste fim de ano, um segredo mal guardado, foi fundada pelos norte-americanos. Não foi fundada por nós. Nunca podemos fundar nenhuma, entendeu? Nossa claque é uma clique de carreiristas, na sua maior parte, tendo, por acaso, algumas pessoas de certo valor, que se associaram com carreiristas nas diversas nações para explorar o que se chama de universo de 'trade', isto é, o comércio das viagens, das conferências, do elogio mútuo, das citações recíprocas. Mas, há uma claquinha, ou claquote que se criou, parece, na Colômbia. Não pude ir para denunciar porque, nesse momento, estava me nascendo um filho, e não é de 
bom tom deixar os filhos nascerem sozinhos. Então, não pude ir lá para fazê-lo. Virei a Brasília, se acaso, esse congresso vier a se realizar aqui, como parece que ele vai se realizar.

Pergunta:

“A noção de periferia, no âmbito da geografia, vem sendo, a meu ver, muito limitada, pois se restringe a visão simplista físico-espacial. A economia, por exemplo, já conceituou mais abrangentemente. Vou tentar trazer um conceito marxista de renda diferencial, conceito esse originalmente referente à terra agrícola. Há teorização sobre o que seja periferia. A sociologia, por sua vez, já define de maneira diferente”...

Você, particularmente, como define a periferia urbana, Cláudia? Já tinham me falado de você, antes. É muito bom vê-la, pessoalmente, também. Olha, eu tenho a impressão que, em alguma parte, eu escrevi a respeito disso. Não me lembro onde. O fato de que a periferia está no polo, quer dizer a periferia não está só na periferia geográfica, mas ela esta dentro do polo. Quer dizer, as periferias sociais que estão dentro do polo. Essa ideia de polo-periferia, que, parece, se deve a Chile (?), não? De que foi reelaborada de forma magistral pelo nosso colega John Friedmann, que é uma importante cabeça da Ciência Regional nos Estados Unidos, e é uma noção que, às vezes, aparece como equívoca, no sentido que ela trás na seu bojo a formulação da necessidade final de polarizar, como algo que é indispensável ao crescimento, que permitirá o crescimento e, depois, a redistribuição. Me parece que essa sua pergunta é muito importante também por isso, porque ela mostra que a polarização é também a polarização dos pobres. O crescimento urbano é um instrumento de atração dos pobres, que vêm para a cidade, sobrecarregando o mercado de trabalho, asseguram a possibilidade dos custos baixos do salário, o que atualmente se chama a reprodução da força de trabalho. Esse discurso novo de certo marxismo universitário e vulgar, que se contenta do gagarrismo e que fala da reprodução da força de trabalho, da superexploração da força de trabalho, contada em quilo de açúcar ou em litro de feijão. E, de outro lado, do superlucro sem se preocupar com o que está entre os processos, que é uma forma de demagogia própria a certo intelectual esquerdista brasileiro, isto é, o gosto da frase, a moda de uma nova ideia, que dura cinco ou seis anos como a tal da Teoria da Dependência, que causou um grande mal aos estudos da realidade brasileira e latino-americana, um dos maiores serviços prestados ao imperialismo nesse continente. E agora tem essa outra coisa, a força de trabalho e não sei o que mais, e que permite fazer grandes cursos sobre o número de horas que se gasta para comprar feijão, para comprar não sei o que, enquanto que os processos que levam a isso não são simplesmente examinados.

Pois bem, acho que a periferia dentro dos centros pode merecer uma preocupação muito grande de nossa parte, tem que merecer. Eu tentei desenvolver aquela teoria sobre os Dois Circuitos da Economia Urbana, livro que já reescrevi inteiramente, porque ele já esta velho. Foi publicado em 1975, é um livro velhíssimo. Então, desgraçadamente, 
penso que não vou poder publicar porque nenhum editor vai reinvestir. Ele vai preferir reimprimir o livro. Exatamente há uma série de colocações que faço e que estão escritas em minha casa. Elas estão à disposição de quem quiser utilizar, exatamente prolongando o debate ao problema interior das cidades e também ao espaço extraurbano e que me parece que vão ter ainda certa validade, apesar das mudanças todas que o mundo vem sofrendo e vai continuar a sofrer.

Não tem mais perguntas?

Saint Clair Versiani:

"Bem, como é sabido, o Centro Acadêmico de Geografia e Historia se reuniu hoje, depois dos debates aqui, na parte da manhã, e resolveu fazer uma pequena análise do encontro e soltar uma nota sobre o quanto que tem acontecido até agora e nos estamos achando e tudo mais. Então vou ler a nota do Centro Acadêmico.”

"Vimos por meio desta, salientar o que consideramos de extrema importância esse atual momento de frutífera discussão que se verifica no seio da geografia. Em primeiro lugar, consideramos que a Semana vem servindo para suscitar uma maior conscientização acadêmica e profissional por parte dos geógrafos, conscientização essa proveniente de discussões que não temos no dia-a-dia das salas de aula. Trata-se, pois, de um fórum de debates que gostaríamos que fosse estendido daqui para frente na rotina acadêmica. Assim, lançamos os alunos de geografia o desafio, qual seja, cobrar de cada professor em sala de aula discussões mais aprofundadas, mais comprometidas sobre os reais problemas que nos cercam enquanto alunos e trabalhadores que somos ou seremos.

Em segundo lugar, queremos participar aos presentes o caráter da organização dessa Semana. O Centro Acadêmico muito se esforçou pela realização desse encontro e finalmente ao lado dos professores mais receptivos à ideia, o concretizamos. Porém, é importante participar-lhes o longo e árduo caminho que foi o da preparação do encontro. Muitos foram os obstáculos desde ordens burocráticas até o descomprometimento de alguns elementos mordidamente passivos. Mas, cremos que todo o esforço empreendido obteve importantes frutos e o principal, foi termos presenciado através da emoção racional, exposta pelos anos de vivência do geógrafo Milton Santos à violência política, que nos intimida no dia-a-dia de forma sutil, às vezes, e mesmo numa sala como esta, onde pretensamente a realidade crua, amarga, triste, pessimista, ou que seja, deveria em tese ser discutida sem censura. Dizer o real não é pessimismo crônico. O crônico é, na verdade, o embotamento de uma consciência crítica, que permeia muitos indivíduos sobre o nosso atual e já caduco regime. Devemos ainda lembrar que a universidade pelo menos teoricamente é o palco de ideias, debates, análise crítica dos inúmeros problemas vividos no dia-a-dia. Devemos fazer da teoria uma prática, não nos deixando abater por todos os obstáculos opressores que fatalmente continuarão a surgir, enquanto radicais transformações não ocorrerem. 
Antes de mais nada, é preciso ter coragem de pensar para ter coragem de dizer e agir. A ação deve ser baseada num questionamento amplo, pois as coisas que parecem claras, em dados momentos, por uma falsa visão do real, pode nos levar a uma mediocridade científica.

Cumprimentamos assim, todos aqueles que pensam e que agem em prol de uma maior justiça social e, em particular, a Milton Santos e ainda mais por ter aceitado nosso convite mesmo que ele tenha partido da mesma universidade que outrora o recusou como membro. Apesar disso, enfatizamos aqui a existência de um frustrado desejo da parte dos alunos no sentido de tê-lo aqui como nosso mestre. Esperamos que não leve de Brasília uma impressão generalizada a cerca da ingenuidade de uns poucos.

Nossos agradecimentos finais, até aqui, a todos aqueles que participaram positivamente dessa semana.

Subscrevem: alunos da geografia reunidos em Assembléia do Centro Acadêmico no dia 16/10/1980. (Muitas palmas)

Coordenador Aldo Paviani

Pergunto ao plenário se há alguma outra colocação a fazer?

\section{Professor Milton Santos:}

Então, quero dizer que estive imensamente feliz de, aqui, ver passar essas horas. Foram horas extremamente felizes para mim. Imagino que fiz bons amigos e companheiros de trabalho. A gente vai continuar trabalhando. Os obstáculos são próprios da vida de cada um de nós e seria horrível se não houvesse esses obstáculos e as palavras de Saint Clair, traduzindo excelsa gentileza e generosidade dos jovens constitui para mim um prêmio como tão grande jamais recebi.

Apenas quero dizer-lhes que a dialética ela existe e existirá tanto, enquanto existe a realidade. A gente deve agradecer sempre as oportunidades que permitem exercermos essa dialética e, por conseguinte, agradeço a todas as pessoas que intervieram no debate, sem exceção, porque esse debate me permitiu mostrar-me, o que eu sempre desejei ser e espero poder continuar sendo, isto é, um homem livre. (Muitas palmas)

Coordenador Aldo Paviani

Ao encerrar os trabalhos na tarde de hoje, quero, em nome do corpo docente e discente, e mesmo porque não, do Decanato de Extensão da UnB, ao Departamento de Geografia e ao Instituto de Ciências Humanas, os nossos agradecimentos pela colaboração. 
Sabendo como o professor Milton Santos é ocupado. Dizia-me ele que enquanto viaja e faz conferências não tem tempo para pensar. Mas, nós verificamos que a sua presença, aqui, foi extremamente estimulante a nós e aos jovens e que, talvez, a repercussão das suas colocações, aqui, sejam bastante grandes para vermos que aquilo que ele pensou, que, às vezes, "a conferência fica no ar” é digerida não se efetive, isto é, que a raiz colocada, ou semente colocada, frutifique e que nós possamos, no futuro, contar com outras oportunidades como esta, de ouvi-lo entre nós.”

Muito obrigado Professor Milton Santos. Conte conosco!! (Palmas)

Trabalho enviado em setembro de 2010

Trabalho aceito em julho de 2011 